\title{
SYNTAXONOMY AND ECOLOGY OF BLACK ALDER VEGETATION IN THE SOUTHERN PART OF CENTRAL SLOVAKIA
}

\author{
Michal SLEZÁK ${ }^{1,2}$, Richard HRIVNÁK ${ }^{3}$ \& Anna PETRÁŠOVÁ ${ }^{4}$
}

\begin{abstract}
The study presents phytosociological and ecological data from azonal black alder forest sites in the southern part of central Slovakia. A data set of 29 relevés was collected by authors in vegetation season 2010 following the standard Braun-Blanquet approach. Numerical classification was performed to delimit the main vegetation types, while statistical analyses were applied to explain the vegetation-environmental relationships. Three associations within two classes were distinguished using a TWINSPAN algorithm. Carici elongatae-Alnetum glutinosae Schwickerath 1933 is an alder carr forest occurring on waterlogged soils in spring fed areas and alluvial zones along rivers. Carici acutiformis-Alnetum glutinosae Scamoni 1933 represents an alder carr forest on habitats with stagnant or slowly flowing water along water courses and artificial water reservoirs. Mesic to humid stands along small brooks are typical for the riparian alder vegetation of Stellario-Alnetum glutinosae Lohmeyer 1957. A detailed description of the floristic and ecological features of these associations is presented. The major environmental gradients affecting variation in species composition of these communities were interpreted as a response of vegetation to soil moisture and nutrient availability regarding the Ellenberg indicator values (moisture and nutrients) and measured variables (total $\mathrm{N}$ and $\mathrm{C}$ ).

Key words: Alnus glutinosa, forest plant communities, numerical classification, ordination, phytosociology, the Western Carpathians.
\end{abstract}

\section{Izvleček}

V članku so predstavljeni fitosociološki in ekološki podatki iz azonalnih gozdov črne jelše v južnem delu osrednje Slovaške. V vegetacijskem obdobju leta 2010 smo naredili 29 popisov po standardni Braun-Blanquetovi metodi. Z numerično klasifikacijo smo opredelili glavne vegetacijske tipe, s statističnimi metodami pa pojasnili povezavo med vegetacijo in okoljskimi dejavniki. Z algoritmom TWINSPAN smo ločili tri asociacije znotraj dveh razredov. V asociacijo Carici elongatae-Alnetum glutinosae Schwickerath 1933 uvrščamo jelševe greze na rastiščih $\mathrm{z}$ visoko talno vodo ob potokih in na aluvialnih ravninah ob rekah. Asociacija Carici acutiformis-Alnetum glutinosae Scamoni 1933 predstavlja jelševe gozdove na rastiščih z zastajajočo ali počasi tekočo vodo ob vodotokih in umetnih vodnih telesih. Mezofilni do vlažni sestoji ob majhnih potokih so značilni za asociacijo Stellario-Alnetum glutinosae Lohmeyer 1957. V članku so podrobno opisane floristična sestava in rastiščne značilnosti teh asociacij. Glavni ekološki gradienti, ki se kažejo v vrstni sestavi, so talna vlaga in hranila. Med Ellenbergovimi indikatorskimi vrednostmi sta to vlažnost in hranila, med merjenimi spremenljivkami pa skupni $\mathrm{N}$ in $\mathrm{C}$.

Ključne besede: Alnus glutinosa, gozdne rastlinske združbe, numerična klasifikacija, ordinacija, fitosociologija, Zahodni Karpati.

\footnotetext{
${ }^{1}$ Faculty of Education, Catholic University, Hrabovská cesta 1, SK-034 01 Ružomberok, Slovak Republic; e-mail: slezak. miso@gmail.com

${ }^{2}$ Institute of Forest Ecology, Slovak Academy of Sciences, Štúrova 2, SK-960 53 Zvolen, Slovak Republic

${ }^{3}$ Institute of Botany, Slovak Academy of Sciences, Dúbravská cesta 9, SK-845 23 Bratislava, Slovak Republic; e-mail: richard.hrivnak@savba.sk

${ }^{4}$ Faculty of Natural Sciences, Matej Bel University, Tajovského 40, SK-974 01 Banská Bystrica, Slovak Republic; e-mail: anniepetrasov@gmail.com
} 


\section{INTRODUCTION}

The eco-physiological adaptive strategies and mechanisms of alder species (e.g. fixation of atmospheric nitrogen) allow development of canopy-closed forest vegetation on heavy, wet and anaerobic soils. They are primarily concentrated on low-lying damp and riparian localities of alluvial and marshland ecosystems. Black alder (Alnus glutinosa) is generally considered to be a typical tree species that tolerates waterlogged soil conditions and a high groundwater table, but it can be found on sites with a wide range of soil moisture, acidity and nutrient status (McVean 1953, Claessens et al. 2010). Considerable fragmentation of Alnus glutinosa forests has commonly been attributed to the distinctive site requirements and conversion of these stands to agricultural landscape (Döring-Mederake 1990). Depth and fluctuation of the groundwater table is crucial for the establishment of this vegetation. Alder carr forests of Alnion glutinosae alliance, which usually occupy waterlogged soils with a high groundwa- ter table and its low fluctuation, have been traditionally classified into the separate class Alnetea glutinosae. On the other hand, floodplain forests occurring on fluvial sediments along rivers and streams with a fluctuating groundwater table are assigned to the Alnion incanae alliance within the class of deciduous forests Querco-Fagetea. This syntaxonomical concept is broadly accepted in the territory of Central Europe (cf. Pott 1992, Solomakha 1996, Willner \& Grabherr 2007, Douda 2008, Kevey 2008, Matuszkiewicz 2008) and is also consistent with the classification system of alder forest vegetation in Slovakia (Jarolímek et al. 2008).

In Slovakia, accessible phytosociological data about plant communities of the Alnion glutinosae alliance have been collected mainly in lowlands, Inner-Carpathian basins and foothills of the $\mathrm{Vy}$ soké Tatry Mts, less often in lower mountains (e.g. Šomšák 1961, 2000, Berta 1970, 1993, Kliment \& Watzka 2000, Hrivnák et al. 2009). The majority of the published relevés represents $C a$ rici elongatae-Alnetum glutinosae and Caltho laetae-

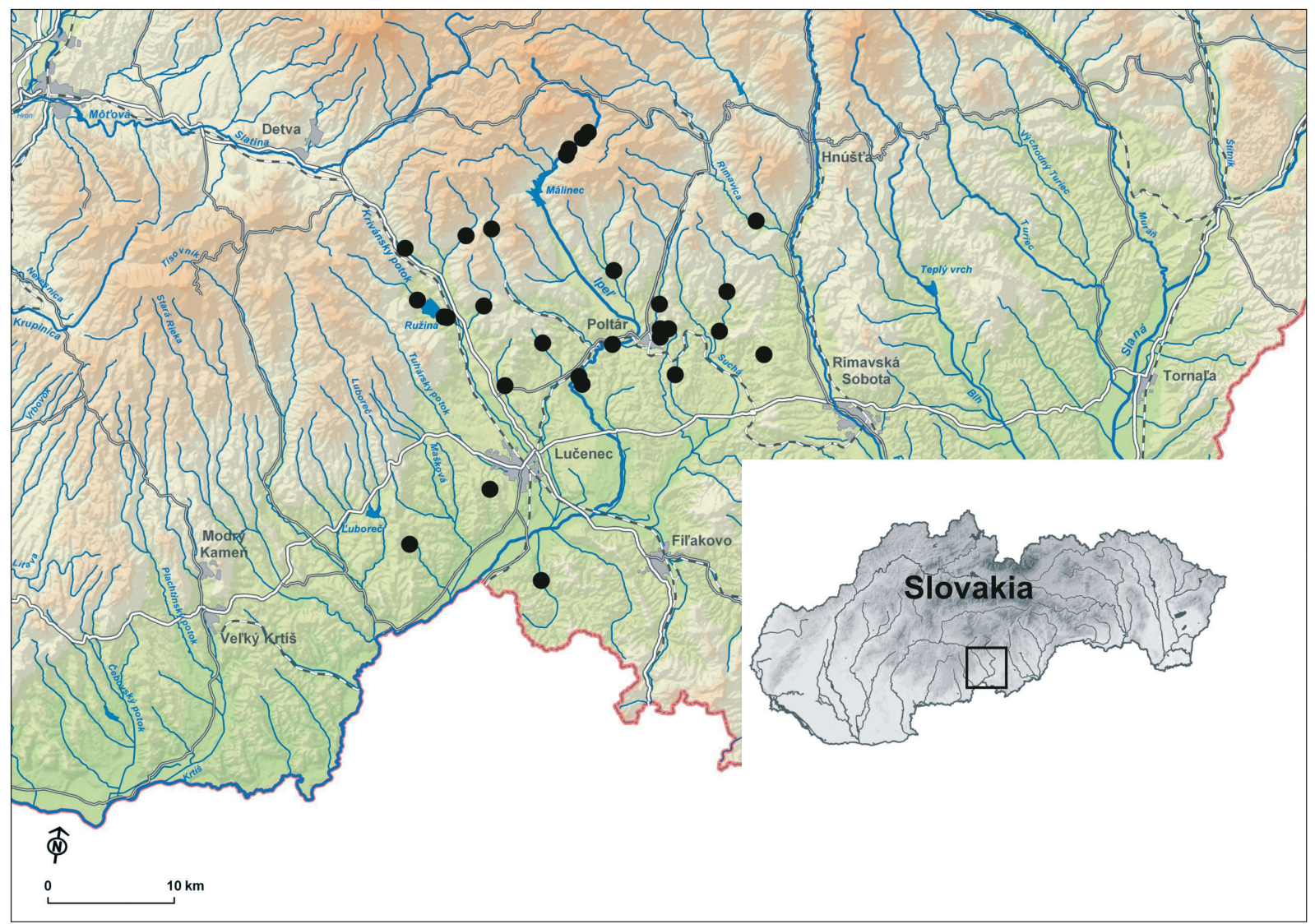

Figure 1: Map of the study area (southern part of central Slovakia) with the localities of individual phytosociological relevés. Slika 1: Karta raziskovanega območja (južni del osrednje Slovaške) s kraji posameznih fitocenoloških popisov. 
Alnetum glutinosae associations, whereas only a little information is available on the distribution, floristic pattern and the overall structure of the other vegetation types (e.g. Hottonio-Alnetum association). Forest communities of the Alnion incanae alliance settle various microhabitats from colline to montane belt of the Western Carpathians. The species composition of the tree layer alternates depending on the site conditions, but Alnus incana, A. glutinosa and Fraxinus excelsior are frequently observed as dominants. Among these communities, only Alnetum incanae and Stellario-Alnetum glutinosae have already been a matter of detailed discussion (Jurko 1961, Miadok 1978).

The southern part of central Slovakia (Novohrad region; Figure 1), situated on the boundary between the Pannonian and Western Carpathian phytogeographic region, belongs to the territories with scarce phytosociological data about alder forest vegetation. Although several localities with this azonal vegetation are known in the study area, it has not been documented yet, except for two relevés of Querceto-Carpinetum alnetosum Mikyška 1939 (Mikyška 1939) and one relevé of Aegopodio-Alnetum glutinosae Šomšák 1961 (Balázs 1996). The latter author provided a basic synopsis of alder-wood communities in the adjacent area (Cerová vrchovina Mts). For this reason, we decided to characterize the phytosociological, ecological and chorological status of alder forest vegetation in the Novohrad region in the wider national context.

\section{METHODS}

The broadleaved forest vegetation with Alnus glutinosa was studied according to the principles of the Braun-Blanquet approach (Westhoff \& van der Maarel 1973). Sampling units were vegetation plots with at least $50 \%$ cover of Alnus glutinosa in the tree layer. The cover of both vascular plants and bryophytes was recorded using the extended nine-degree Braun-Blanquet sampling scale (Barkman et al. 1964). Twenty-nine phytosociological relevés were collected by authors in the southern part of central Slovakia (Figure 1) in 2010 and stored in a TURBOVEG database (Hennekens \& Schaminée 2001). Numerical classification of the data set was performed by TWINSPAN algorithm (Hill 1979) in the JUICE program (Tichý 2002). Three pseudospecies cut levels corresponding to the cover values $0 \%$, $5 \%$ and $25 \%$ were applied. The same species recorded in several layers (especially woody species) were merged into one layer for the purpose of numerical classification. Within the recorded species, aggregate taxa Rubus hirtus and R. fruticosus were classified into the broadly defined taxon $R$. fruticosus agg. The moss layer was also included in the analysis. The final form of classification was confirmed through analysis of the data set involving also phytosociological relevés of original diagnosis of detected communities (cf. Schwickerath 1933, Scamoni 1935, Mikyška 1968, Lohmeyer 1957, Neuhäuslová 2003).

Diagnostic species for each group of relevés were determined using the concept of fidelity (Sokal \& Rohlf 1995, Chytrý et al. 2002), frequency and constancy (difference of three constancy classes) for individual taxa. The measure of species concentration in vegetation units was quantified by phi coefficient. Threshold values of phi coefficient and frequency for the species to be considered as diagnostic were set to 0.20 and 40 , respectively. Fisher's exact test $(P<0.05)$ was applied to eliminate the fidelity value of species with a non-significant pattern of occurrence. The percentage constancy (frequency) was given for each species in individual clusters and they were ranked by the decreasing value (Table 1).

The linear method, Principal component analysis (PCA) from the CANOCO 4.5 package (ter Braak \& Šmilauer 2002) was used to explain major environmental gradients in the species composition. Species percentage cover was square-root transformed. Unweighted Ellenberg indicator values for vascular plants (Ellenberg et al. 1992) and selected ecological data (altitude, soil reaction and conductivity, content of $\mathrm{C}, \mathrm{N}$, $\mathrm{C} / \mathrm{N}$ ratio, content of sand, silt and clay in soil, presence of open water on soil surface as the nominal variable) for relevés were plotted onto the PCA ordination diagram as supplementary variables. These values were correlated with the position of the relevés on the first two ordination axes using the Pearson correlation coefficient. Normality for environmental variables was tested with the Shapiro-Wilk W test and homogeneity (equality) of variance with Levene's test. Since some of the variables were not normally distributed, they were log-transformed prior to analysis. The significance of differences in variables among the clusters was tested with the one-way ANOVA and post-hoc Newman-Keuls test (Ta- 
ble 2). The Kruskal-Wallis ANOVA was applied for multiple comparisons only in case of an Ellenberg indicator value for moisture regarding the violation of normality assumption. The STATISTICA software (StatSoft 2001) was used for statistical analysis.

Soil samples were randomly taken in three places in each vegetation plot from the uppermost mineral horizon (0-10 cm depth, litter removed) and mixed to form a single sample per plot in order to reduce the soil heterogeneity. They were dried at a laboratory temperature, crushed and passed through a $2 \mathrm{~mm}$ sieve. The proportion of sand, silt and clay was assessed with a Laser analyzer (Fritsch GmbH Analysette 22; Germany) in which ultrasonic and sodium hexametaphosphate $\left[\left(\mathrm{NaPO}_{3}\right)_{6}\right]$ were applied for disaggregating. Soil $\mathrm{pH}$ and conductivity were measured in distilled water (1:5 soil: water ratio) using the $\mathrm{pH}$ meter (WTW Inolab pH 720) and conductivity meter (WTW Inolab Cond 720), respectively. The $\mathrm{C} / \mathrm{N}$-ratio was calculated based on the total carbon and total nitrogen content determined by the NCS-FLASH 1112 analyzer. The geographical coordinates (WGS-84), altitude and aspect of the vegetation plots were measured by Garmin GPSmap 60 CSx equipment and controlled on the topographic map with a scale $1: 50000$.

Nomenclature of bryophytes and vascular plants follows the checklist by Marhold \& Hindák (1998), and the names of plant communities and their syntaxonomical position are in accordance with Jarolímek et al. (2008). Full scientific name of vegetation units with author's name and year of description were used in cases when they were not presented in the above-mentioned paper. Nomenclature of associations, along with the synonyms including only the names frequently used in Slovakia, was revised following the rules of the International Code of Phytosociological Nomenclature (Weber et al. 2000).

\section{RESULTS}

TWINSPAN classification of Alnus glutinosa-dominated forests (Table 1) resulted in determination of four main relevé groups corresponding to traditionally recognized associations of Alnetea glutinosae and Querco-Fagetea classes. These groups were clearly differentiated by floristic composition and ecology. The syntaxonomical survey of the studied vegetation types is as follows:
Class: Alnetea glutinosae Br.-Bl. et R. Tx. ex Westhoff et al. 1946

Order: Alnetalia glutinosae R. Tx. 1937

Alliance: Alnion glutinosae Malcuit 1929

Association: Carici elongatae-Alnetum glutinosae Schwickerath 1933

Carici acutiformis-Alnetum glutinosae Scamoni 1935

Class: Querco-Fagetea Br.-Bl. et Vlieger in Vlieger 1937

Order: Fagetalia Pawłowski in Pawłowski et al. 1928

Alliance: Alnion incanae Pawłowski in Pawłowski et al. 1928

Association: Stellario-Alnetum glutinosae Lohmeyer 1957

variant Galium aparine

typical variant

Description of detected plant communities

Carici elongatae-Alnetum glutinosae Schwickerath 1933 (Table 1, cluster A, relevés 1-5)

Original form of the name: Schwickerath (1933): Cariceto elongatae-Alnetum glutinosae

Nomenclatural type: Schwickerath (1933): rel. 117, holotypus

Synonyms: Carici elongatae-Alnetum glutinosae Koch 1926 (Art. 2b), Alnus glutinosa-Molinia coerulea Šmarda 1951 (syntax. syn.), Cariceto elongataeAlnetum medioeuropaeum (Koch 1926) R. Tx. et Bodeux 1955 (Art. 34a), Alnus glutinosa-Dryopteris spinulosa-Ass. Klika 1940 (syntax. syn.).

This community is represented by alder carr forests growing in spring fed areas and alluvial zones along rivers. Most often, they constitute relatively small stands at altitudes of 370-462 m. The physiognomy of the tree layer is determined by Alnus glutinosa, whereas Corylus avellana, Fraxinus excelsior, Cerasus avium and Frangula alnus frequently appear in the shrub layer. The heterogeneous habitat conditions lead to the mosaic structure of the herb layer. It is mostly formed by dominant Caltha palustris (Figure 2), but other plants (e.g. Circaea lutetiana) can also be found with a higher cover. The stands are well-differentiated through the spring species (Cardamine amara, Chaerophyllum hirsutum and Crepis paludosa) accompanied by numerous bryophytes (Calliergonella cuspidata, Climacium dendroides, Lophocolea heterophylla, Plagiothecium denticulatum and Rhizomnium punctatum) showing high fidelity to this association. The common presence of Carex elon- 


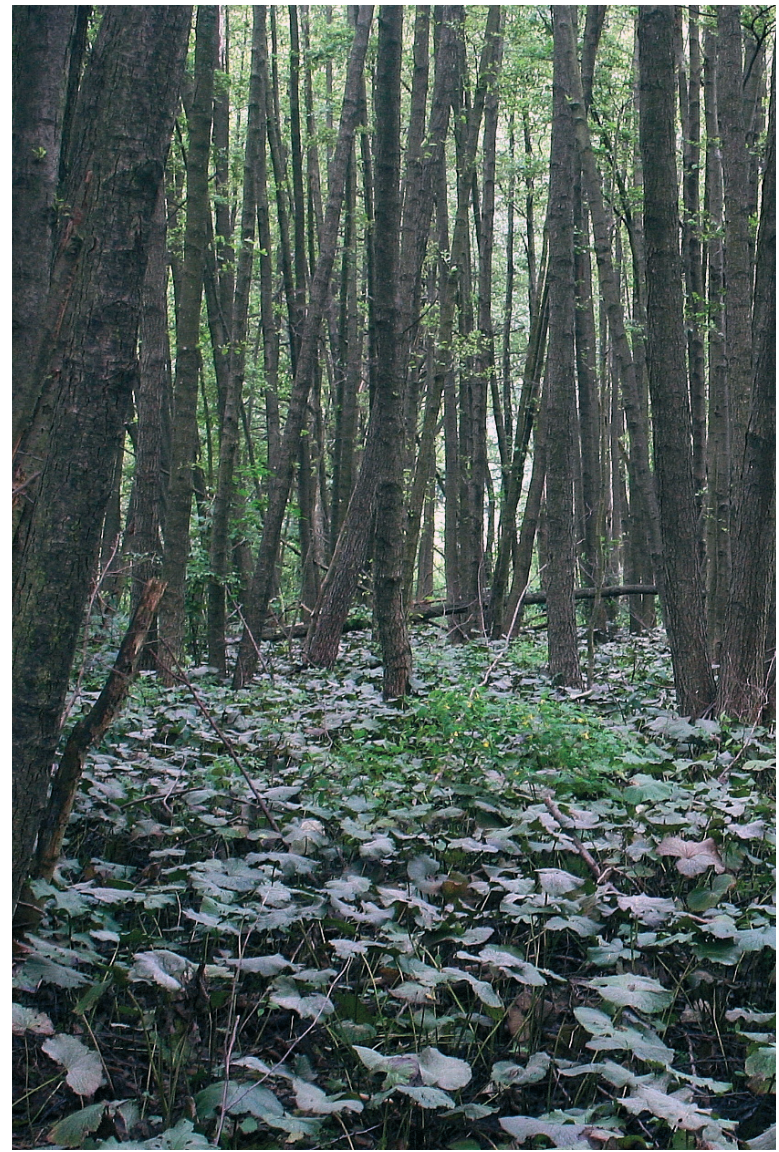

Figure 2: Carici elongatae-Alnetum glutinosae with dominant species Caltha palustris (Photo: M. Slezák, 29. 7. 2010, Ipel'ský Potok).

Slika 2: Carici elongatae-Alnetum glutinosae z dominantno vrsto Caltha palustris. Foto: M. Slezák, 29. 7. 2010, Ipel'ský Potok.

gata, Scutellaria galericulata and Valeriana dioica supports assignment of this vegetation unit to the Alnion glutinosae alliance. Species of the Calthion palustris alliance, together with a species-rich group of hygrophilous elements (e.g. Carex remota, Chrysosplenium alternifolium, Filipendula ulmaria, Galium palustre, Impatiens noli-tangere, Lysimachia nummularia, L. vulgaris, Ranunculus repens and Scirpus sylvaticus), are characterized by high constancy. Floristic spectrum is enriched by several shade-tolerant ferns and herbs, such as Ajuga reptans, Athyrium filix-femina and Dryopteris carthusiana. The moss layer plays an important role in the community structure. In addition to the above-mentioned diagnostic species, the diverse cryptogamic flora includes mainly generalists of wet habitats (Atrichum undulatum, Brachythecium rivulare and Plagiomnium affine).

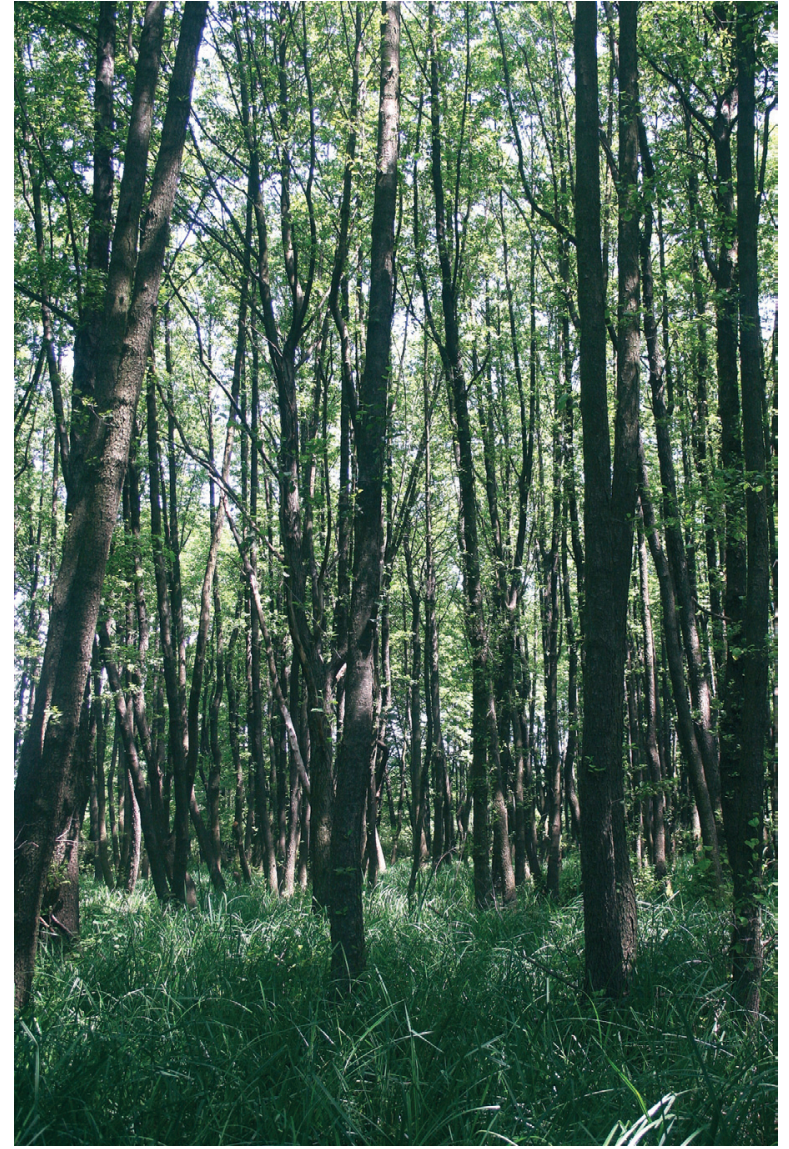

Figure 3: Physiognomy of the herb layer within the Carici acutiformis-Alnetum glutinosae is formed by Carex acutiformis (Photo: M. Slezák, 30. 6. 2010, Divín).

Slika 3: Fiziognomijo zeliščne plasti asociacije Carici acutiformis-Alnetum glutinosae is gradi vrsta Carex acutiformis. Foto: M. Slezák, 30. 6. 2010, Divín.

Carici acutiformis-Alnetum glutinosae Scamoni 1935 nom. invers. propos. (Table 1 , cluster $\mathrm{B}$, relevés 6-10)

Original form of the name: Scamoni (1935): Alnus glutinosa-Carex acutiformis=Assoziation

Nomenclatural type: Mikyška (1968): 14-20, Tab. 1, rel. 8, neotypus (Neuhäuslová 2003)

Synonyms: Alnus glutinosa-Phragmites communis Šmarda 1951 (syntax. syn.).

These medium, open to closed canopy alder carr forests with dominance of Carex acutiformis (Figure 3) are situated along water courses and in the upper littoral of artificial water reservoirs. They thrive on sites with stagnant water on soil surface (Figure 4) in the colline belt (210-297 m a.s.l.). The water level may occasionally decrease for a short time during the summer, but soil remains still swampy or moist. The homogeneous 


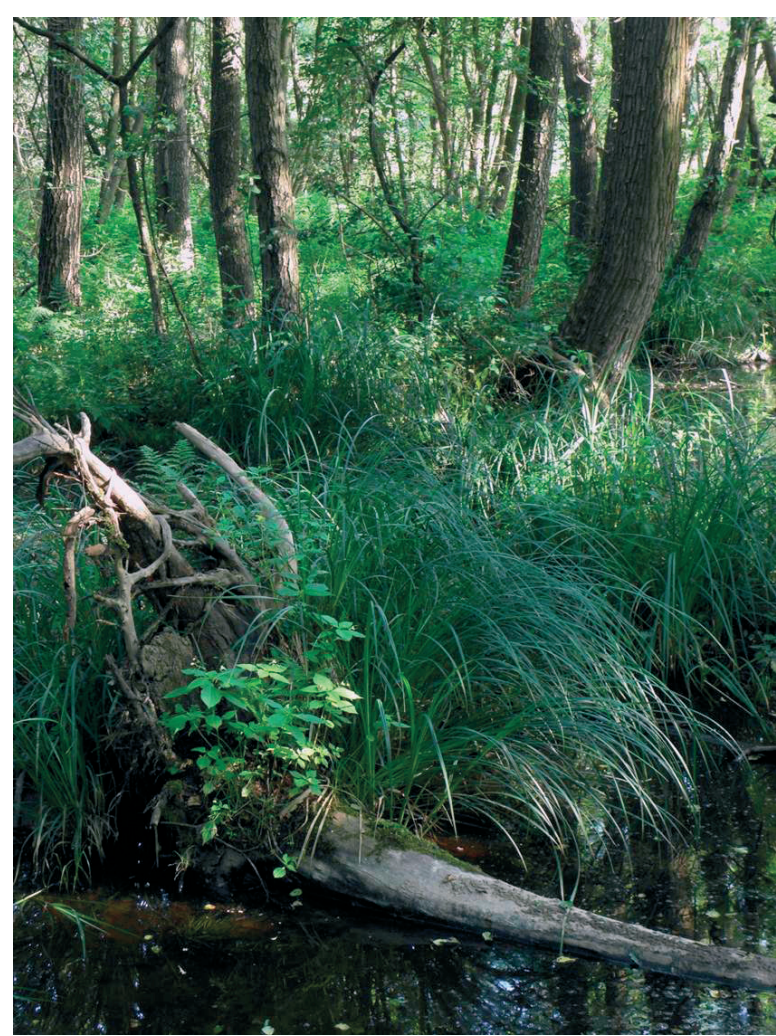

Figure 4: Carici acutiformis-Alnetum glutinosae with open water on soil surface (Photo: R. Hrivnák, 30. 6. 2010, Lovinobaňa). Slika 4: Carici acutiformis-Alnetum glutinosae s stoječo vodo na površini. Foto: R. Hrivnák, 30. 6. 2010, Lovinobaňa.

tree layer is exclusively built up of Alnus glutinosa. Except for the younger individuals of tree species in the weakly developed shrub layer, shade-tolerant species such as Frangula alnus, Swida sanguinea and Viburnum opulus are locally admixed. Besides the tall-sedge Carex acutiformis, the peculiar feature of the floristic spectrum is the occurrence of marshland species including Equisetum fluviatile, Glyceria fluitans and Iris pseudacorus. The herb layer displays a significant number of vascular plants with affinities to eutrophic wet meadows (Caltha palustris, Filipendula ulmaria, Galium palustre, Lysimachia vulgaris and Poa trivialis). The group of nitrophilous and liana species along with some ferns (Athyrium filix-femina, Dryopteris carthusiana, Humulus lupulus, Lycopus europaeus, Persicaria hydropiper, Scirpus sylvaticus and Solanum dulcamara) are constantly present, while nutrient-demanding species classified into the Querco-Fagetea class are less abundant (Table 1). Higher coverage of Urtica dioica (Table 1, rel. 6 ) indicates successive degradation of the stand which has been attributed to the soil drying (cf.

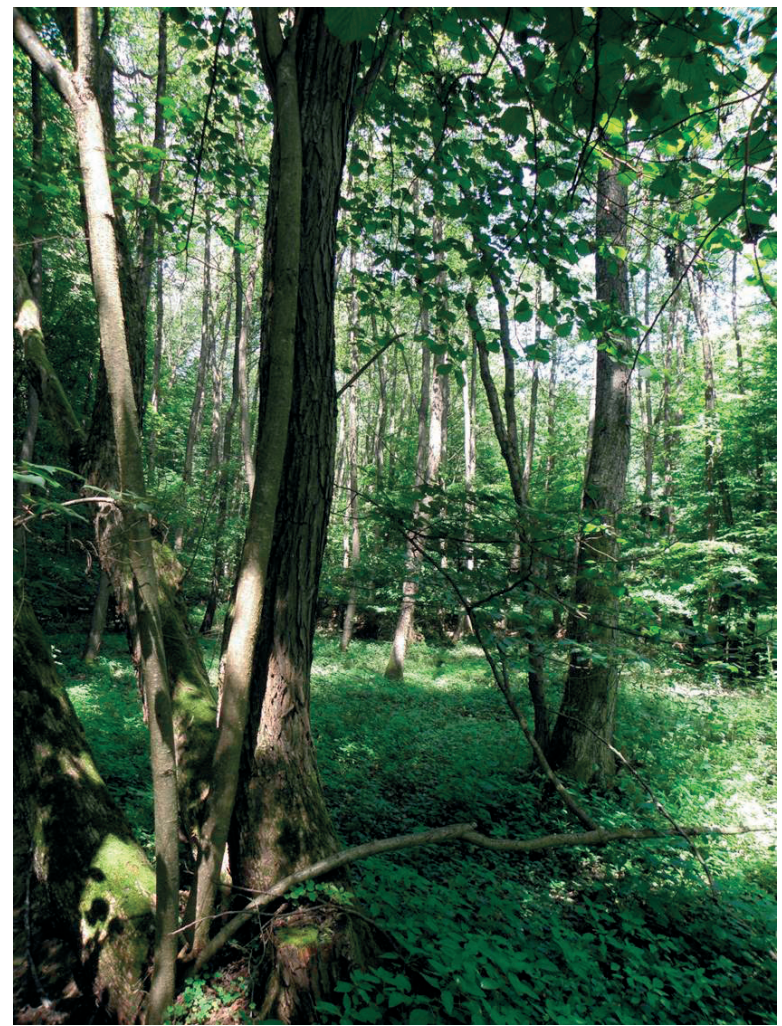

Figure 5: Three-layered stand of Stellario-Alnetum glutinosae (Photo: R. Hrivnák, 8. 6. 2010, Kalinovo).

Slika 5: Troplastni sestoj asociacije Stellario-Alnetum glutinosae. Foto: R. Hrivnák, 8. 6. 2010, Kalinovo.

Neuhäuslová 2003). The species-poor moss layer is predominantly consisting of Brachythecium rivulare and Atrichum undulatum, but none of them reaches higher cover values.

Stellario-Alnetum glutinosae Lohmeyer 1957 (Table 1 , cluster $\mathrm{C}$, relevés 11-29)

Original form of the name: Lohmeyer (1957): Stellario-Alnetum glutinosae [Kästner 1938]

Nomenclatural type: Lohmeyer (1957): Tab. 1, rel. 17, lectotypus (Neuhäuslová 2000)

Synonyms: Querceto-Carpinetum alnetosum Mikyška 1939 (syntax. syn.).

The eutrophic riparian alder forests are distributed along small brooks in the colline belt (219-239 m a.s.1.). The conventionally threelayered stands are most often created by Alnus glutinosa (Figure 5), whereas Salix fragilis is more sporadic in the tree layer. Considerable species diversity of the shrub layer is the distinguishing pattern of this vegetation type. It is primarily formed by saplings of Acer campestre, Alnus glutinosa and Carpinus betulus together with shrubs 
adapted to the wet soil conditions, such as Padus avium, Sambucus nigra and Srida sanguinea. Regular occurrence of numerous mesophilous herbs and species associated with eutrophic sites (Aegopodium podagraria, Galeobdolon luteum, Geranium robertianum, Geum urbanum, Glechoma hederacea agg., Lamium maculatum and Stachys sylvatica) allow classification of Stellario-Alnetum glutinosae within the Fagetalia order and Querco-Fagetea class. In addition to species Athyrium filix-femina and Dryopteris carthusiana, several generalists of floodplain vegetation (Carex remota, Circaea lutetiana, Equisetum arvense, Lysimachia nummularia, L. vulgaris, Persicaria hydropiper, Poa trivialis and Urtica dioica) grow in the herb layer. The most common bryophytes are Brachythecium rivulare and Plagiomnium undulatum.

Two different vegetation types on the level of variant were identified depending on the moisture gradient. The Stellario-Alnetum glutinosae variant with Galium aparine (Table 1, cluster C1) inhabits more humid sites that are often modified by floods. These ecological conditions enable successful establishment and growth of more vascular plant species with diverse moisture requirements, including Carex remota, Deschampsia cespitosa, Galium aparine, Funcus effusus, Padus avium $\left(\mathrm{E}_{2}\right)$, Scirpus sylvaticus and Veronica beccabunga. A typical variant (Table 1, cluster C2) is located on similar habitats, but these are often surrounded by mixed oak-hornbeam forests of Carpinion betuli alliance. In spite of some hygrophilous elements (e.g. Chrysosplenium alternifolium, Persicaria maculosa and Stellaria nemorum), these stands are characterized mainly by higher frequency and cover of mesophilous forest species (Ajuga reptans, Brachypodium sylvaticum, Galeobdolon luteum, Lamium maculatum, Oxalis acetosella and Pulmonaria obscura).

\section{ECOLOGICAL GRADIENTS}

The quantitative analysis of the vegetation-environmental data matrix revealed a clear floristic and ecological differentiation of alder vegetation. The passive projection of Ellenberg indicator values onto the PCA ordination diagram pointed out the main compositional gradient (axis 1) which can be interpreted as the response of vegetation to moisture and available soil nutrients (Figure 6). In this sense, nutrient content decreases from the left to the right part of the scatter-plot,

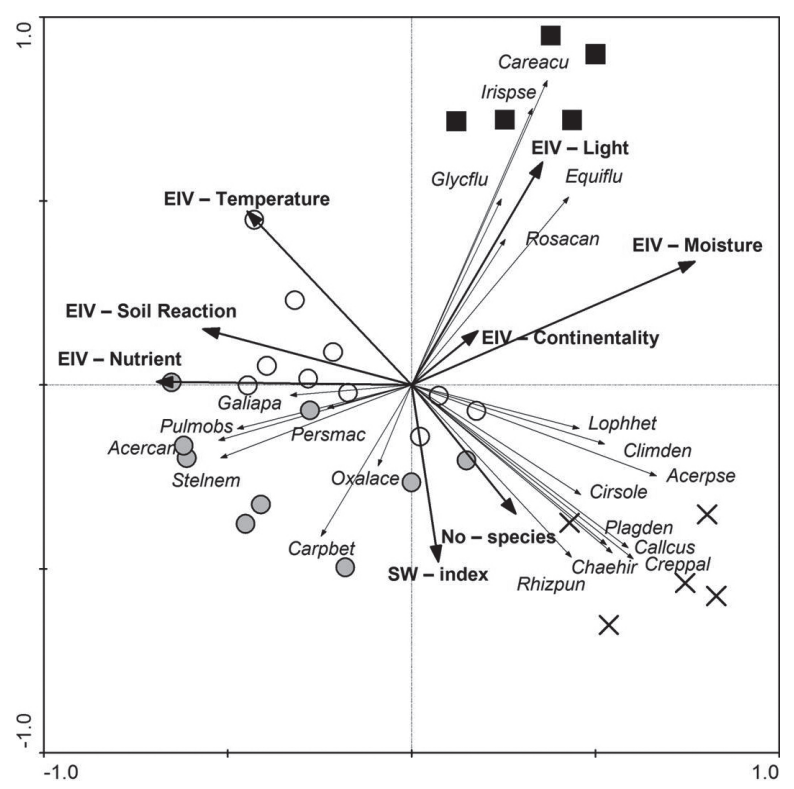

Figure 6: PCA ordination diagram of both species and samples of alder vegetation with Ellenberg indicator values as supplementary environmental variables. The first two ordination axes explain $14.9 \%$ and $10.6 \%$ of the total species variability, respectively. Full squares - Carici acutiformis-Alnetum glutinosae; crosses - Carici elongatae-Alnetum glutinosae; full circles - Stellario-Alnetum glutinosae variant typical; empty circles - Stellario-Alnetum glutinosae variant Galium aparine. Pearson correlation coefficients with the first two PCA axes $\left({ }^{*} P<0.01\right.$; ns: $\left.P>0.01\right)$ : Shannon-Wiener index (SW - index; 0.073ns and $-0.480^{*}$ ), Number of species (No - species; $0.283 \mathrm{~ns}$ and $-0.351 \mathrm{~ns})$, Light $\left(0.356 \mathrm{~ns}\right.$ and $\left.0.605^{\star}\right)$, Temperature $\left(-0.447^{\star}\right.$ and $\left.0.472^{\star}\right)$, Continentality $(0.180 \mathrm{~ns}$ and $0.146 \mathrm{~ns})$, Moisture $\left(0.771^{\star}\right.$ and $\left.0.336 \mathrm{~ns}\right)$, Soil reaction $\left(-0.567^{\star}\right.$ and $\left.0.152 \mathrm{~ns}\right)$, Nutrients $\left(-0.693^{\star}\right.$ and $\left.0.008 \mathrm{~ns}\right)$.

Only diagnostic species for individual communities are shown (Acercam - Acer campestre, Acerpse - Acer pseudoplatanus, Callcus - Calliergonella cuspidata, Careacu - Carex acutiformis, Carpbet - Carpinus betulus, Chaehir - Chaerophyllum hirsutum, Cirsole - Cirsium oleraceum, Climden - Climacium dendroides, Creppal - Crepis paludosa, Equiflu - Equisetum fluviatile, Galiapa - Galium aparine, Glycflu - Glyceria fluitans, Irispse - Iris pseudacorus, Lophhet - Lophocolea heterophylla, Oxalace - Oxalis acetosella, Persmac - Persicaria maculosa, Plagden - Plagiothecium denticulatum, Pulmobs - Pulmonaria obscura, Rhizpun - Rhizomnium punctatum, Rosacan - Rosa canina agg., Stelnem - Stellaria nemorum).

Slika 6: Ordinacijski diagram PCA z vrstami in popisi jelševe vegetacije in Ellenbergovimi indikatorskimi vrednostmi kot dodatnimi okoljskimi spremenljivkami. Prvi dve osi pojasnita $14,9 \%$ in $10,6 \%$ celotne vrstne variabilnosti. Polni kvadrati - Carici acutiformis-Alnetum glutinosae, križi - Carici elongatae-Alnetum glutinosae, polni krogi - Stellario-Alnetum glutinosae, tipična varianta, prazni krogi - Stellario-Alnetum glutinosae, varianta Galium aparine. Pearsonov korelacijski koeficient s prvima dvema osema PCA $\left({ }^{\star} P<0,01\right.$; ns: $\left.P>0,01\right)$ : Shannon-Wienerjev indeks (SW - index; $0,073 \mathrm{~ns}$ in $-0,480^{\star}$ ), 
Število vrst (No - species; 0,283ns in $-0,351 \mathrm{~ns})$, svetloba $\left(0,356\right.$ ns in $\left.0,605^{\star}\right)$, temperatura $\left(-0,447^{\star}\right.$ in $\left.0,472^{\star}\right)$, kontinentalnost $(0,180 \mathrm{~ns}$ in $0,146 \mathrm{~ns})$, vlažnost $\left(0,771^{*}\right.$ in $\left.0,336 \mathrm{~ns}\right)$, reakcija tal $\left(-0,567^{\star}\right.$ in $\left.0,152 \mathrm{~ns}\right)$, hranila $\left(-0,693^{\star}\right.$ in $\left.0,008 \mathrm{~ns}\right)$.

Prikazane so samo diagnostične vrste posameznih združb (Acercam - Acer campestre, Acerpse - Acer pseudoplatanus, Callcus - Calliergonella cuspidata, Careacu - Carex acutiformis, Carpbet - Carpinus betulus, Chaehir-Chaerophyllum hirsutum, Cirsole - Cirsium oleraceum, Climden - Climacium dendroides, Creppal - Crepis paludosa, Equiflu - Equisetum fluviatile, Galiapa - Galium aparine, Glycflu - Glyceria fluitans, Irispse - Iris pseudacorus, Lophhet - Lophocolea heterophylla, Oxalace - Oxalis acetosella, Persmac - Persicaria maculosa, Plagden - Plagiothecium denticulatum, Pulmobs - Pulmonaria obscura, Rhizpun - Rhizomnium punctatum, Rosacan - Rosa canina agg., Stelnem - Stellaria nemorum).

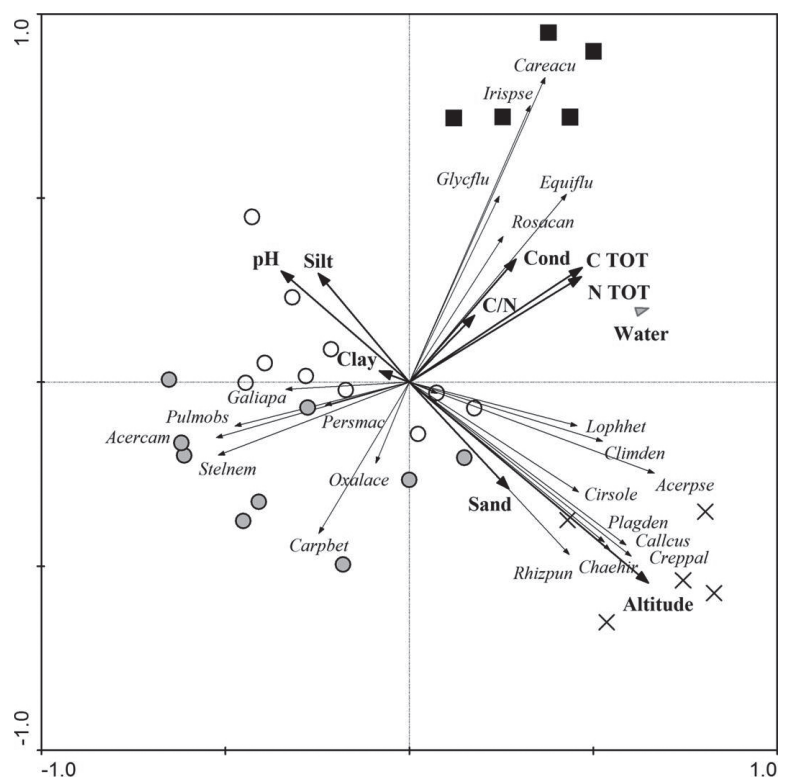

Figure 7: PCA ordination diagram of both species and samples of alder vegetation with directly measured ecological data. The first two ordination axes explain $14.9 \%$ and $10.6 \%$ of the total species variability, respectively. Full squares - Carici acutiformis-Alnetum glutinosae; crosses - Carici elongataeAlnetum glutinosae; full circles - Stellario-Alnetum glutinosae variant typical; empty circles - Stellario-Alnetum glutinosae variant Galium aparine; full triangle (water) - presence of open water on soil surface as nominal variable. Pearson correlation coefficients with the first two PCA axes $\left({ }^{*} P<0.01\right.$; ns: $P>0.01)$ : altitude $\left(0.650^{\star}\right.$ and $\left.-0.546^{*}\right)$, soil reaction $(\mathrm{pH}$; $-0.348 \mathrm{~ns}$ and $0.302 \mathrm{~ns}$ ), soil conductivity (Cond; $0.290 \mathrm{~ns}$ and $0.334 \mathrm{~ns})$, content of C (C TOT; $0.469^{*}$ and $\left.0.311 \mathrm{~ns}\right)$, content of $\mathrm{N}\left(\mathrm{N}\right.$ TOT; $0.467^{*}$ and $\left.0.287 \mathrm{~ns}\right), \mathrm{C} / \mathrm{N}$ ratio $(\mathrm{C} / \mathrm{N} ; 0.177 \mathrm{~ns}$ and $0.182 \mathrm{~ns}$ ), content of sand (Sand; 0.270ns and $-0.290 \mathrm{~ns}$ ), content of silt (Silt; $-0.247 \mathrm{~ns}$ and $0.296 \mathrm{~ns}$ ), content of clay (Clay; -0.082ns and 0.030ns).

Only diagnostic species for individual communities are shown (for the explanation of species abbreviations see Figure 6). while the moisture gradient shows the inverse tendency. Consequently, individual communities are arranged from riparian alder vegetation with numerous mesophilous and nutrient-demanding species (Stellario-Alnetum glutinosae) to alder carr forests with a large group of hygrophilous plant specialists (Carici elongatae-Alnetum glutinosae and Carici acutiformis-Alnetum glutinosae). The results of PCA analysis with measured characteristics identified the altitude and content of total $\mathrm{N}$ and $\mathrm{C}$ as variables controlling species composition within alder vegetation (Figure 7). Moreover, the presence of open water on soil surface represents an important ecological parameter for establishment of alder carr forests of Alnion glutinosae alliance.

Significant differences were found in Ellenberg indicator values for moisture among the groups of forest stands (Table 2). Besides the evident relation of alder carr forests to marshland habitats, the soils are also characterized by a higher content of total $\mathrm{N}$ and C. Furthermore, the Carici acutiformis-Alnetum glutinosae association (Table 2, cluster B) exhibits the highest light-requirements. This finding seems to be a response to the extreme site conditions (periodically waterlogged soils with limited aeration) leading to mosaic structure of the tree layer. At the same time, our analysis indicates the partially more montane character of the Carici elongataeAlnetum glutinosae association (significant differences in altitude and temperature; Table 2, cluster A), whereas the other vegetation types display similarities in these ecological factors.

Slika 7: Ordinacijski diagram PCA z vrstami in popisi jelševe vegetacije $\mathrm{z}$ neposredno merjenimi ekološkimi podatki. Prvi osi pojasnita $14,9 \%$ in $10,6 \%$ celotne vrstne variabilnosti. Polni kvadrati - Carici acutiformis-Alnetum glutinosae, križi - Carici elongatae-Alnetum glutinosae, polni krogi - Stellario-Alnetum glutinosae, tipična varianta, prazni krogi - Stellario-Alnetum glutinosae, varianta Galium aparine, polni trikotniki (voda) - prisotnost odprte vodne površine kot nominalna spremenljivka. Pearsonov korelacijski koeficient s prvima osema PCA $\left({ }^{*} P<0,01\right.$; ns: $P>0,01)$ : višina $\left(0,650^{*}\right.$ in $\left.0,546^{*}\right)$, reakcija tal $(\mathrm{pH} ;-0,348 \mathrm{~ns}$ in $0,302 \mathrm{~ns}$ ), konduktivnost (Cond; $0,290 \mathrm{~ns}$ in $0,334 \mathrm{~ns}$ ), vsebnost C (C TOT; $0,469^{*}$ in $\left.0,311 \mathrm{~ns}\right)$, vsebnost $\mathrm{N}$ (N TOT; $0,467^{*}$ in $\left.0,287 \mathrm{~ns}\right), \mathrm{C} / \mathrm{N}$ razmerje $(\mathrm{C} / \mathrm{N} ; 0,177 \mathrm{~ns}$ in $0,182 \mathrm{~ns})$, vsebnost peska (Sand; 0,270ns in -0,290ns), vsebnost melja (Silt; -0,247ns in 0,296ns), vsebnost gline (Clay; -0,082ns in 0,030ns).

Prikazane so samo diagnostične vrste posameznih združb (za razlago okrajšav glej sliko 6). 


\section{DISCUSSION}

The floristic spectrum and spatial variability of plant species in black alder forest stands are generally affected by hydrological regime (depth of the groundwater table and its seasonal dynamic), nutrient availability and specific relief structure. The heterogeneity of surface with waterlogged hollows and drier hummocks is evident, particularly in alder carr forests (Klika 1940, Döring 1987, Solińska-Górnicka 1987). In contrast, the relatively uniform micro-topography and considerable annual variation of groundwater table are typical features of riparian alder forests. Although both above-mentioned vegetation types share a certain proportion of common species able to thrive in a wide range of environmental conditions (cf. Prieditis 1997, Douda 2008), they are conspicuously separated by their species composition. Consequently, the first level of TWINSPAN classification divided the total data set of Alnus glutinosa-dominated forests from the southern part of central Slovakia into two main groups (Table 1); Euro-Siberian alder carr vegetation ( $A l$ nion glutinosae, Alnetea glutinosae) with constant presence of marshland and hygrophilous species, and European broad-leaved floodplain forests (Alnion incanae, Querco-Fagetea) with an abundant group of mesophilous herbs. This division into two alliances is in accordance with the traditional syntaxonomical concept commonly used in most European vegetation overviews. Partial inconsistency has been observed only in position of Alnion incanae alliance within the higher syntaxa; Willner \& Grabherr (2007), Douda (2008), Kevey (2008), Matuszkiewicz (2008) and Onyshchenko (2010) assign this alliance to the Querco-Fagetea class, but according to Rodwell et al. (2002) and Tzonev et al. (2009) it belongs to the Populetea albae Br.-Bl. 1962 class.

Plant communities presented in our study (Stellario-Alnetum glutinosae, Carici elongatae-Alnetum glutinosae and Carici acutiformis-Alnetum glutinosae) differ in the stand structure, species composition and their affinity to ecological parameters (Table 1,2). The various participation of hygrophilous elements in the herb layer of Stellario-Alnetum glutinosae resulted in delimitation of two different variants, one on typical mesic stands (Table 1, cluster C2) and the other on more humid sites (Table 1, cluster C1). Variability of floristic composition along the soil moisture gradient in this vegetation type was already found by Neuhäuslová-Novotná (1972), Neuhäuslová \& Kolbek (1993) and Neuhäuslová (2000). In the study area, Mikyška (1939) and Balázs (1996) assigned black alder forest stands to QuercetoCarpinetum alnetosum (two relevés) and AegopodioAlnetum glutinosae (one relevé). Regarding their overall species composition and ecology, they are very similar to the just discussed eutrophic riparian alder forests and might be classified as the Stellario-Alnetum glutinosae association. From syntaxonomical point of view, the occurrence of a forest stand with the tall fern Matteuccia struthiopteris (Table 1, rel. 20) is interesting. Besides the Matteuccio-Alnetum incanae association described by Hadač \& Terray (1989) from the Bukovské vrchy Mts in north-east Slovakia, forest communities with dominance of Matteuccia struthiopteris and prevalence of hemi- and nitrophilous vascular plants in species-poor herb layers are largely classified in Matteuccio-Alnetum glutinosae association (cf. Kliment \& Watzka 2000). Despite the partial coincidence either in dominating species or in the presence of common mesophilous and hygrophilous species (e.g. Aegopodium podagraria, Chrysosplenium alternifolium, Galium aparine, Glechoma hederacea agg., Impatiens noli-tangere), several species characteristic for Matteuccio-Alnetum glutinosae are lacking (Dentaria glandulosa, Geranium phaeum, Myosotis scorpioides agg.). This is one of the reasons for ranking the relevé (Table 1, rel. 20) into the Stellario-Alnetum glutinosae.

The eutrophic riparian alder forests of Stellario-Alnetum glutinosae and alder carr forests of Carici elongatae-Alnetum glutinosae are distributed across Slovakia (Miadok 1978, Šomšák 2000, Žarnovičan 2008, Slezák et al. 2011), although in the last decades many stands have disappeared due to drainage and stream regulation. In spite of the relatively frequent occurrence of suitable habitats with stagnant or slowly flowing water, especially within alluvial zones in the southern part of the country, the Carici acutiformis-Alnetum glutinosae association has not been well documented with relevés (e-dataset stored in Slovak Phytosociological Database; http://ibot.sav.sk/ cdf/index.html).

The vegetation of Alnion glutinosae alliance is widespread from lowlands to submontane areas in the temperate zone of Europe (Bodeux 1955, Ellenberg 1982). Outside Slovakia, analogous communities with similar floristic structure and identical physiognomy have been often reported under different names and accepted in various 
rates. In Poland, instead of Carici elongatae-Alnetum glutinosae, Solińska-Górnicka (1987) introduced a new classification of these forests within the associations Sphagno squarrosi-Alnetum Solinska-Górnicka (1975) 1987 (acidophilous bog moss alder carr) and Ribo nigri-Alnetum SolińskaGórnicka (1975) 1987 (mesotrophic alder carr). The Carici acutiformis-Alnetum glutinosae have been recently published only from lowlands and foothills of the Czech Republic (Douda 2008). This community has not been recognised as a separate vegetation unit by syntaxonomical revision of the Austrian data set (Willner \& Grabherr 2007). Relevés, assigned to this association by previous authors, were included in the Carici elongatae-Alnetum subas. caricetosum acutiformis Pfadenhauer 1969. Our results support the concept of two associations which was already reported by Neuhäuslová (2003) and Douda (l.c.). This separation is based on the noticeable differences in their diagnostic and dominant species, habitat conditions, structure and physiognomy (Table 1, Figure 6,7$)$ as well as on comparison with the original diagnosis (cf. Schwickerath 1933, Scamoni 1935, Mikyška 1968, Neuhäuslová l.c.).

The ecological singularity of Alnion glutinosae azonal forest vegetation is emphasized through their peculiar sites and soil properties. Stagnant water and/or permanently waterlogged soils cause a decline of mineralization rate leading to an accumulation of organic matter along with increase of $\mathrm{N}$ content. Therefore, the higher values of total $\mathrm{N}$ and $\mathrm{C}$ content in these soils (Table 2, cluster 1, 2) are consistent with those reported by Paal et al. (2007) and Naqinezhad et al. (2008). In the study area, affinity of Carici elongatae-Alnetum glutinosae to higher altitudinal areas reflects only the local possibilities of environmental conditions (Table 2, cluster $1 ; 370-462 \mathrm{~m}$ a.s.l.), since these forests in Slovakia can be found from 130 to $670 \mathrm{~m}$ a.s.l. (Šomšák 2000). Our observations are thus in the middle of this range. Although the other measured parameters varied among sites, they mostly exhibited no statistically significant differences (Table 2). This is probably due to the relatively uniform characteristics of the geological substrate and limited number of vegetation plots reflecting an abundance of suitable habitats with relevant forest communities. The significant effect of soil moisture, soil reaction and nutrient availability on the species composition and distribution patterns of the presented communities has been published in earlier studies (e.g. Kollár 2001, Douda 2008).

\section{ACKNOWLEDGEMENTS}

We would like to thank Vít Grulich for determination of Carex canescens and C. nigra specimens, Ján Kliment and Milan Chytrý for their help in solving nomenclature questions, and Dagmar Kúdelová for language improvement. The study was supported by the Science Grant Agency of the Ministry of Education of the Slovak Republic and Slovak Academy of Sciences (VEGA 2/0034/10, VEGA 2/0068/10, VEGA 2/0059/11) and the University Grant Agency UMB in Banská Bystrica UGA UMB (Project No. 02/07/2009/2010).

\section{REFERENCES}

Balázs, P. 1996: Jelšiny Cerovej vrchoviny (fytocenologická charakteristika). Ochrana Prírody 14: 29-39.

Barkman, J. J., Doing, H. \& Segal, S. 1964: Kritische Bemerkungen und Vorschläge zur quantitativen Vegetationsanalyse. Acta Botanica Neerlandica 13: 394-419.

Berta, J. 1970: Waldgesellschaften und Bodenverhältnisse in der Theisstiefebene. Vegetácia ČSSR, B1: 1-372.

Berta, J. 1993: Slatinné-jelšové lesy (asociácia Carici elongatae-Alnetum W. Koch 1926) v južnej časti Slánskych vrchov. Biologia 48: 53-59.

Bodeux, A. 1955: Alnetum glutinosae. Mitteilungen der Floristisch-soziologischen Arbeitsgemeinschaft (Stolzenau/Weser) 5: 114-137.

Chytrý, M., Tichý, L., Holt, J. \& Botta-Dukát, Z. 2002: Determination of diagnostic species with statistical fidelity measures. Journal of Vegetation Science 13: 79-90.

Claessens, H., Oosterbaan, A., Savill, P. \& Rondeux, J. 2010: A review of the characteristics of black alder (Alnus glutinosa (L.) Gaertn.) and their implications for silvicultural practices. Forestry 83: 163-175.

Döring, U. 1987: Zur Feinstruktur amphibischer Erlenbruchwälder. Kleinstandörtliche Differenzierungen in der Bodenvegetation des Carici elongatae-Alnetum im Hannoverschen Wendland. Tuexenia 7: 347-366.

Döring-Mederake, U. 1990: Alnion forests in Lower Saxony (FRG), their ecological requirements, classification and position within Carici elongatae-Alnetum of Northern Central Europe. Vegetatio 89: 107-119. 
Douda, J. 2008: Formalized classification of the vegetation of alder carr and floodplain forests in the Czech Republic. Preslia 80: 199-224.

Ellenberg, H. 1982: Vegetation Mitteleuropas mit den Alpen. Ulmer, Stuttgart, 989 pp.

Ellenberg, H., Weber, H. E., Düll, R., Wirth, W., Werner, W. \& Paulißen, D. 1992: Zeigerwerte von Pflanzen in Mitteleuropa. Scripta Geobotanica 18: 1-258.

Hadač, E. \& Terray, J. 1989: Wood plant communities of the Bukovské vrchy hills, NE Slovakia. Folia Geobotanica Phytotaxonomica 24: 337-370.

Hennekens, S. M. \& Schaminée, J. H. J. 2001: TURBOVEG, a comprehensive data base management system for vegetation data. Journal of Vegetation Science 12: 589-591.

Hill, M. O. 1979: TWINSPAN. A Fortran program for arranging multivariate data in an ordered two-way table by classification of the individuals and attributes. Cornell University, Ithaca, 66 pp.

Hrivnák, R., Kochjarová, J., Blanár, D. \& Šoltés, R. 2009: Jelšové lesy na Muránskej planine zhrnutie súčasných fytocenologických poznatkov. Reussia 5 (1-2): 23-33.

Jarolímek, I., Šibík, J., Hegedüšová, K., Janišová, M., Kliment, J., Kučera, P., Májeková, J., Michálková, D., Sadloňová, J., Šibíková, I., Škodová, I., Uhlîrová, J., Ujházy, K., Ujházyová, M., Valachovič, M. \& Zaliberová, M. 2008: A list of vegetation units of Slovakia. In: Jarolímek, I. \& Šibík, J. (eds.): Diagnostic, constant and dominant species of the higher vegetation units of Slovakia. Veda, Bratislava, pp. 295-329.

Jurko, A. 1961: Das Alnetum incanae in der Mittelslowakei II. Die Auenwälder in den Westkarpaten. Biologia 16: 321-339.

Kevey, B. 2008: Magyarország erdötársulásai (Forest associations of Hungary). Tilia 14: 1-489.

Klika, J. 1940. Die Pflanzengesellschaften des Alnion-Verbandes. Preslia 18-19: 97-112.

Kliment, J. \& Watzka, R. 2000: Lesné spoločenstvá Drienčanského krasu. In: Kliment, J. (ed.): Príroda Drienčanského krasu. ŠOP SR, Banská Bystrica, pp. 191-214.

Kollár, J. 2001: The Borská nížina lowland black alder forests and their ecological evaluation. Ekológia 20, Suppl. 3: 202-207.

Lohmeyer, W. 1957: Der Hainmieren-Schwarzerlenwald (Stellario-Alnetum glutinosae [Kästner
1938]). Mitteilungen der Floristisch-soziologischen Arbeitsgemeinschaft (Stolzenau/Weser) 6-7: 247-257.

Marhold, K. \& Hindák, F. (eds.) 1998: Zoznam nižších a vyšších rastlín Slovenska. Veda, Bratislava, 688 pp.

Matuszkiewicz, W. 2008: Przewodnik do oznaczania zbiorowisk roślinnych Polski. Wydawnictwo Naukowe PWN, Warszawa, 542 pp.

McVean, D. N. 1953: Alnus glutinosa. Journal of Ecology 41: 447-466.

Miadok, D. 1978: Bachbegleitende Erlenbrüche im nordwestlichen Teil des Gemerské rudohorie-Gebirges. Acta Facultatis Rerum Naturalium Universitatis Comenianae, Botanica 26: 107-115.

Mikyška, R. 1939: Studie über die natürlichen Waldbestände im Slowakischen Mittelgebirge (Slovenské stredohorie). Ein Beitrag zur Soziologie der Karpatenwälder. Beihefte zum Botanischen Centralblatt 59B: 169-244.

Mikyška, R. 1968: Wälder am Rande der Ostböhmischen Tiefebene. Rozpravy Československé Akademie Věd, ser. math.-natur. 78 (4): 1-122.

Naqinezhad, A., Hamzeh'ee, B. \& Attar, F. 2008: Vegetation-environment relationships in the alderwood communities of Caspian lowlands, N. Iran (toward an ecological classification). Flora 203: 567-577.

Neuhäuslová, Z. 2000: Alnion incanae. In: Moravec, J. (ed.): Přehled vegetace České republiky, Svazek 2. Hygrofilní, mezofilní a xerofilní opadavé lesy. Academia, Praha, pp. 15-70.

Neuhäuslová, Z. 2003: Alnetea glutinosae. In: Moravec, J. (ed.): Přehled vegetace České republiky, Svazek 4. Vrbotopolové luhy a bažinné olšiny a vrbiny. Academia, Praha, pp. 41-57.

Neuhäuslová, Z. \& Kolbek, J. 1993: Variability of the association Stellario-Alnetum in the Czech Republic. Fragmenta Floristica et Geobotanica, Suppl. 2 (2): 631-648.

Neuhäuslová-Novotná, Z. 1972: Beitrag zur Kenntnis des Stellario-Alnetum glutinosae (Mikyška 1944) Lohmeyer 1957 in der Tschechischen Sozialistischen Republik (ČSR). Folia Geobotanica Phytotaxonomica 7: 269-284.

Onyshchenko, V. 2010: A revised classification of Ukrainian forests of the order Fagetalia sylvaticae. Tuexenia 30: 31-45.

Paal, J., Rannik, R., Jeletsky, E. M. \& Prieditis, N. 2007: Floodplain forests in Estonia: typological diversity and growth conditions. Folia Geobotanica 42: 383-400. 
Pott, R. 1992: Die Pflanzengesellschaften Deutschlands. Verlag Eugen Ulmer, Stuttgart, 437 pp.

Prieditis, N. 1997: Alnus glutinosa-dominated wetland forests of the Baltic Region: community structure, syntaxonomy and conservation. Plant Ecology 129: 49-94.

Rodwell, J. S., Schaminée, J. H. J., Mucina, L., Pignatti, S., Dring, J. \& Moss, D. 2002: The diversity of European Vegetation. An overview of phytosociological alliances and their relationships to EUNIS habitats. National Reference Centre for Agriculture, Nature and Fisheries, Wageningen, $168 \mathrm{pp}$.

Scamoni, A. 1935: Vegetationsstudien im Sarnow. Zeitschrift für Forst- und Jagdwesen 1935: 561-648.

Schwickerath, M. 1933: Die Vegetation des Landkreises Aachen und ihre Stellung im nördlichen Westdeutschland. Aachener Beiträge zur Heimatkunde 13: 1-135.

Slezák, M., Hegedüšová, K. \& Senko, D. 2011: Syntaxonomy and ecology of forest vegetation in the Štiavnické vrchy Mts (Central Slovakia). Acta Societatis Botanicorum Poloniae 80: 115-127.

Sokal, R. R. \& Rohlf, F. J. 1995: Biometry. $3^{\text {rd }}$ Edition. W. H. Freeman and Company, New York, $887 \mathrm{pp}$.

Solińska-Górnicka, B. 1987: Alder (Alnus glutinosa) carr in Poland. Tuexenia 7: 329-346.

Solomakha, V. A. 1996: The syntaxonomy of vegetation of Ukraine. Ukrainian Phytosociological Collection, Ser. A, 4 (5): 1-121.

Šomšák, L. 1961: Jelšové porasty Spišsko-gemer- ského rudohoria. Acta Facultatis Rerum Naturalium Universitatis Comenianae, Botanica 6: 407-459.

Šomšák, L. 2000: Alnion glutinosae Malcuit 1929 na Slovensku (Západné Karpaty). Acta Facultatis Rerum Naturalium Universitatis Comenianae, Botanica 40: 81-102.

ter Braak, C. J. F. \& Šmilauer, P. 2002: CANOCO Reference manual and CanoDraw for Windows User's guide. Software for Canonical Community Ordination (version 4.5). Microcomputer Power, Ithaca, NY, 500 pp.

Tichý, L. 2002: JUICE, software for vegetation classification. Journal of Vegetation Science 13: 451-453.

Tzonev, R. T., Dimitrov, M. A. \& Roussakova, V. H. 2009: Syntaxa according to the Braun-Blanquet approach in Bulgaria. Phytologia Balcanica 15 (2): 209-233.

Weber, H. E., Moravec, J. \& Theurillat, J. -P. 2000: International Code of Phytosociological Nomenclature. $3^{\text {rd }}$ Edition. Journal of Vegetation Science 11: 739-768.

Westhoff, V. \& van der Maarel, E. 1973: The Braun-Blanquet approach. In: Whittaker, R. H. (ed.): Ordination and classification of communities. Junk, The Hague, pp. 617-727.

Willner, W. \& Grabherr, G. 2007: Die Wälder und Gebüsche Österreichs. Ein Bestimmungswerk mit Tabellen. Spektrum Akademischer Verlag, Heidelberg, 302 pp.

Žarnovičan, H. 2008: Lesné spoločenstvá východnej časti Myjavskej pahorkatiny. Phytopedon 7 (2): 230-239. 


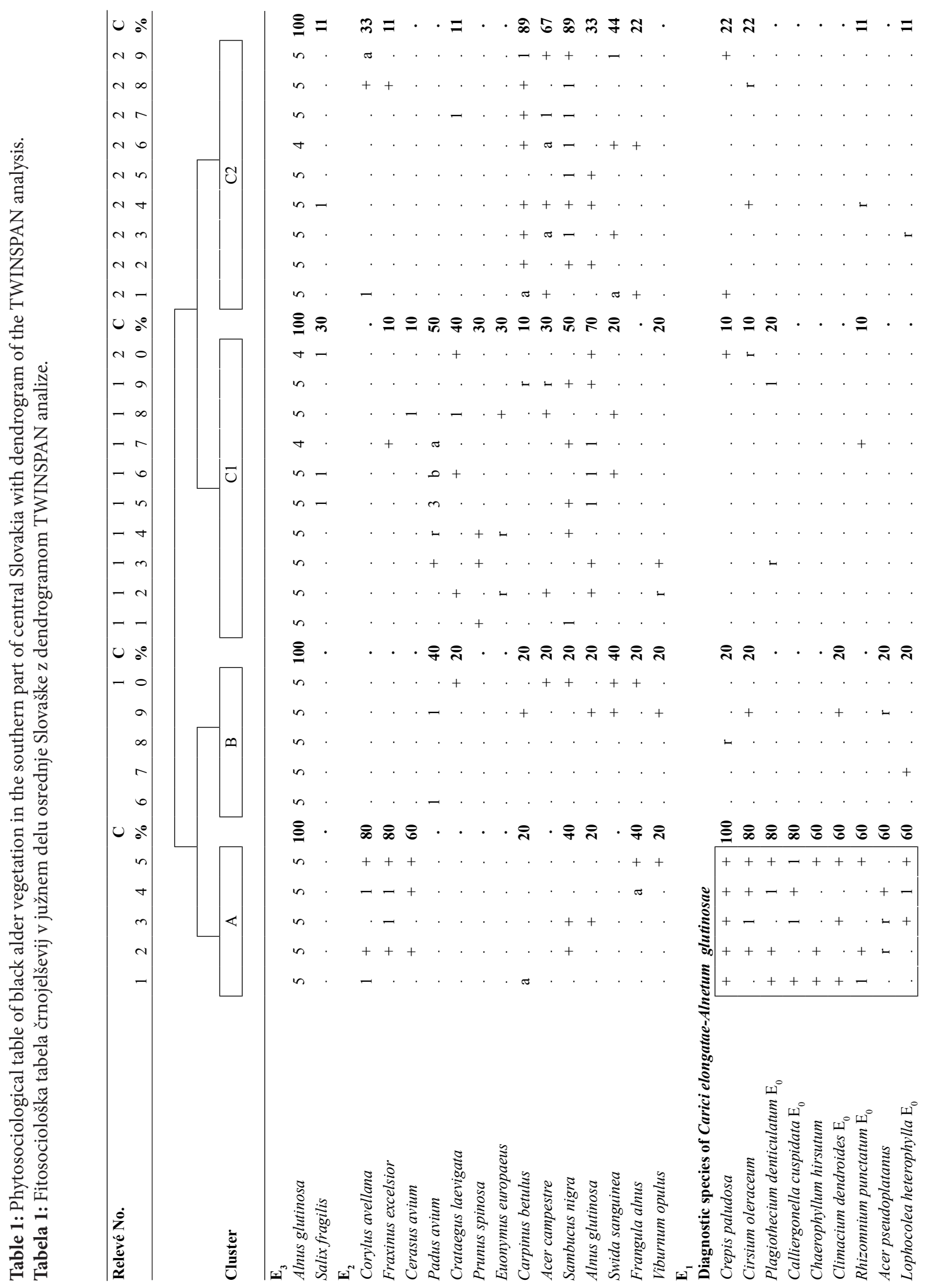




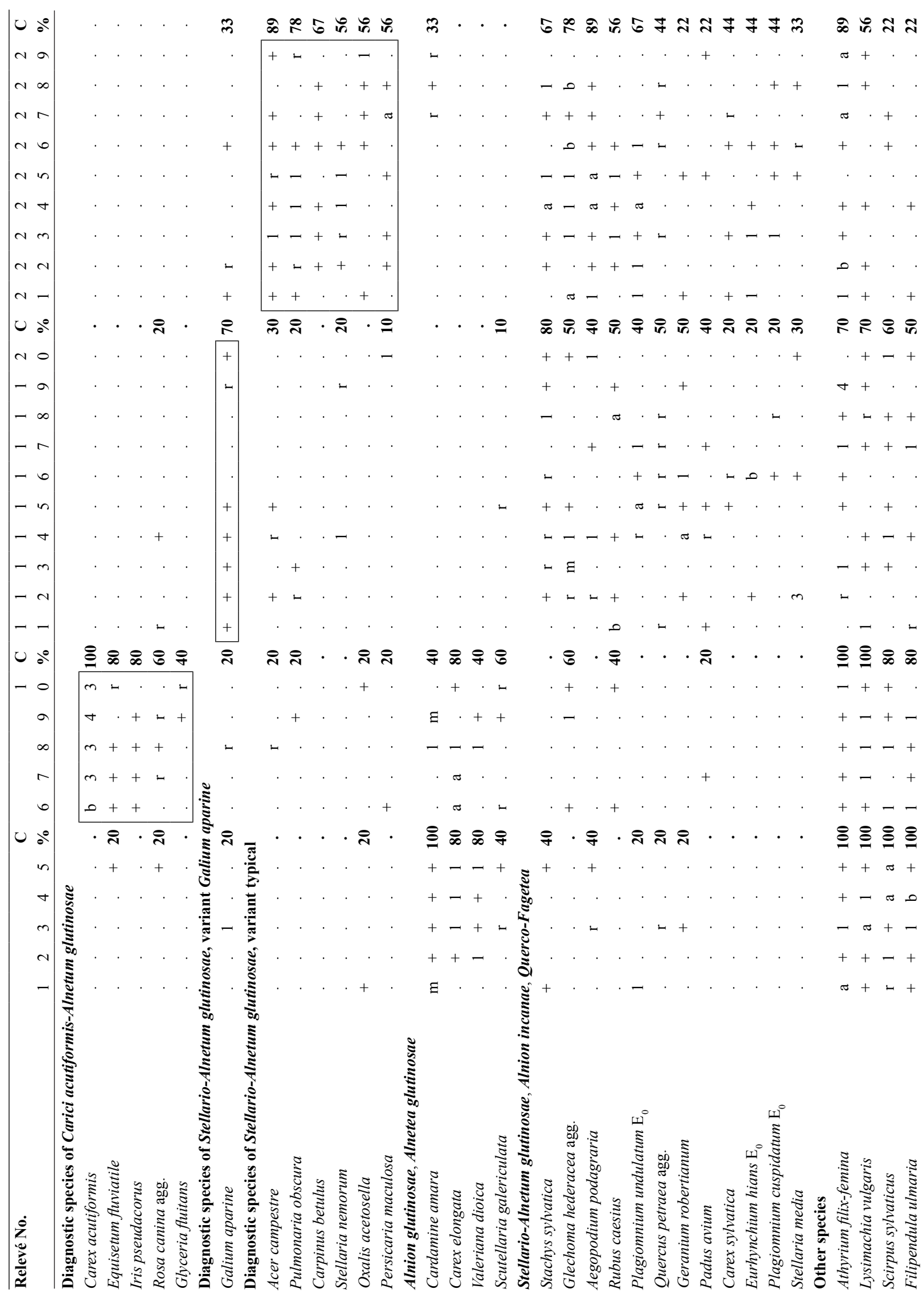




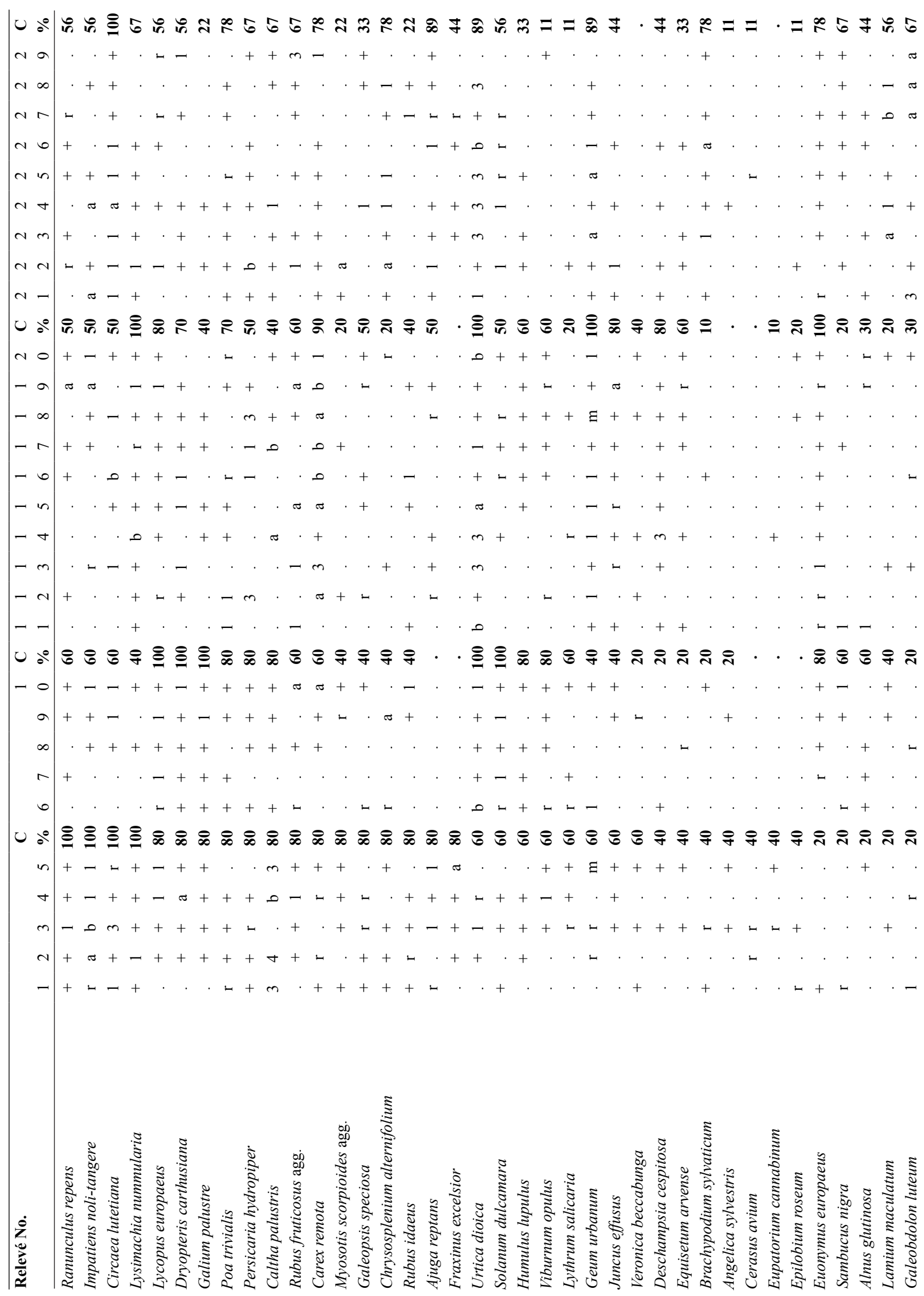




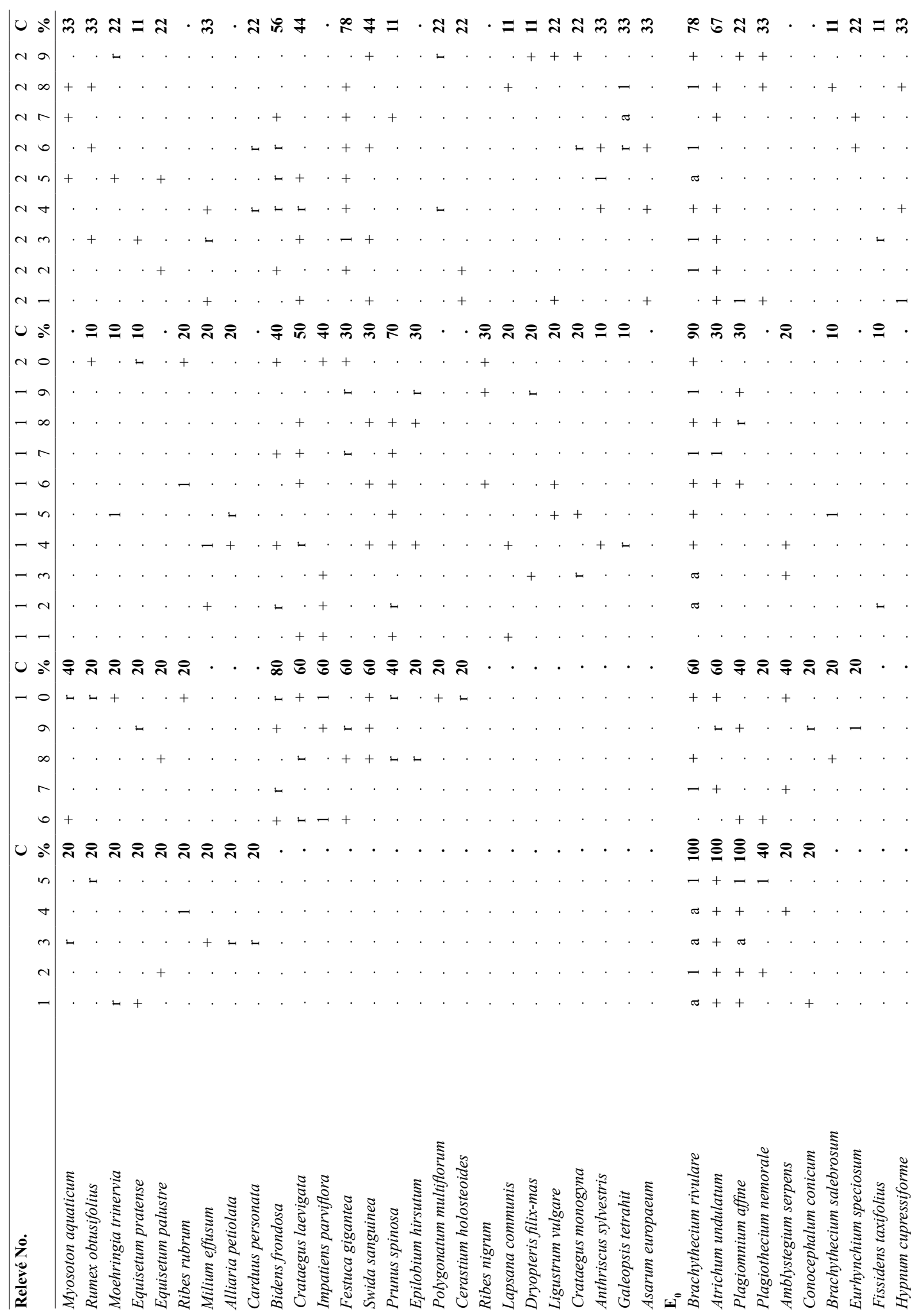


Legend:

A - Carici elongatae-Alnetum glutinosae, B - Carici acutiformis-Alnetum glutinosae, C1 - Stellario-Alnetum glutinosae variant Galium aparine, C2 - Stellario-Alnetum glutinosae variant typical.

Species present only in one or two relevés:

$\mathbf{E}_{3}$ - tree layer: Acer campestre $(23,1)$, Carpinus betulus $(12,+)$, Cerasus avium $(18,1 ; 29,+)$, Fraxinus excelsior $(23,+; 26,1)$, Padus avium $(16,+)$.

$\mathbf{E}_{2}$ - shrub layer: Acer pseudoplatanus (3, +; 23, +), A. tataricum (13, r; 26, +), Crataegus monogyna (13, +; 29, b), Rubus hirtus agg. (11, + ), Salix cinerea $(9,1)$, S. fragilis (20, r), Tilia cordata $(4,+)$, T. platyphyllos $(3,+)$, Ulmus laevis $(20,+)$.

$\mathbf{E}_{1}$ - herb layer: Acer platanoides (5, r), A. tataricum $(26,+)$, Actaea spicata $(1,+)$, Alisma plantago-aquatica $(10,1)$, Alopecurus pratensis $(11,+)$, Anemone nemorosa (28, r), Arctium tomentosum (25, +; 26, +), Bidens tripartita (8, r), Calystegia sepium (11, +), Carex acuta $(4,+; 10,+)$, C. buekii $(11,4)$, C. canescens $(5,+)$, C. muricata agg. $(14,1)$, C. nigra $(1, \mathrm{r})$, C. ovalis $(3, \mathrm{r})$, C. pilosa $(16, \mathrm{r})$, C. vesicaria $(5,1 ; 18,+)$, Chaerophyllum aromaticum $(28,+)$, C. temulum $(28,+)$, Cirsium arvense $(4, r ; 11, r)$, Corylus avellana $(3, r ; 28,+)$, Cruciata glabra $(1,+)$, Cucubalus baccifer $(10,+; 25,+)$, Dactylis glomerata $(28, \mathrm{r})$, Dryopteris dilatata $(1,+; 16,+)$, Echinocystis lobata $(6, \mathrm{r})$, Elytrigia repens $(12,+)$, Equisetum sylvaticum $(3,+; 17,+)$, E. telmateia $(2,+)$, Fallopia dumetorum $(27, \mathrm{r} ; 28,+)$, Fragaria vesca $(16,+)$, Frangula alnus $(4,1)$, Glyceria notata $(16, r)$, Holcus lanatus $(8,+; 22, r)$, Impatiens glandulifera (20, b), Lunaria rediviva (2, r; 28, 1), Lychnis flos-cuculi (22, +), Maianthemum bifolium $(29,+)$, Matteuccia struthiopteris (20, a), Mentha arvensis (9, +; 16, r), M. longifolia (22, r), Molinia caerulea agg. (11, 1), Persicaria lapathifolia (11, r), Peucedanum palustre (7, +), Phragmites australis (6, 1), Picea abies (4, r), Poa palustris (17, r), Prunella vulgaris (22, r), Ranunculus acris $(6, \mathrm{r})$, R. flammula $(10,+)$, R. lanuginosus (1, r; $21, \mathrm{r})$, R. sceleratus $(12,+)$, Roegneria canina $(11, \mathrm{a} ; 20, \mathrm{r})$, Rudbeckia laciniata $(5,+; 22,+)$, Rumex conglomeratus $(22,+), R$. crispus $(12,+; 14, r)$, Scrophularia nodosa $(24, r)$, Sonchus arvensis $(14, r)$, Sorbus aucuparia $(11, r)$, Sparganium erectum $(7,+)$, Stellaria graminea $(2, \mathrm{r})$, S. holostea $(21,+)$, Tilia cordata $(3,+)$, T. platyphyllos $(24,+)$, Torilis japonica $(14, \mathrm{r})$, Tripleurospermum perforatum $(12, \mathrm{r})$, Tussilago farfara $(27, \mathrm{r})$, Valeriana officinalis agg. $(8, \mathrm{r} ; 14, \mathrm{r})$, Viola reichenbachiana $(16,+)$.

$\mathbf{E}_{0}$ - moss layer: Brachythecium reflexum $(3,+)$, Bryum subelegans $(7,+)$, Ceratodon purpureus $(7,+)$, Chiloscyphus pallescens $(1,+)$, Dicranella heteromalla $(7,+)$, Fissidens bryoides $(12, \mathrm{r})$, Herzogiella seligeri $(2,+)$, Pellia epiphylla $(1, \mathrm{a})$, Physcomitrium pyriforme $(12,+)$, Plagiothecium cavifolium $(5,+)$, P. undulatum $(29,+)$, Platygyrium repens $(28,+)$, Polytrichum formosum $(12, \mathrm{r})$, Thuidium delicatulum $(5,1)$.

\section{Locations of relevés}

Relevé number, locality-village (full headers with higher accuracy location of individual relevés are presented in the Slovak Phytosociological Database; http://ibot.sav.sk/cdf/index.html), altitude (m), aspect (in letters), slope (degrees), relevé area, total cover $\left(E_{t}\right)$, cover of tree layer $\left(E_{3}\right)$, cover of shrub layer $\left(E_{2}\right)$, cover of herb layer $\left(E_{1}\right)$, cover of mosses and lichens $\left(E_{0}\right)$, longitude, latitude, date (day/month/year), relevé author.

1. Hrnčiarky, 370 m, N, 5, 400 m²$^{2}, \mathrm{E}_{\mathrm{t}} 80 \%, \mathrm{E}_{3} 80 \%, \mathrm{E}_{2} 10 \%, \mathrm{E}_{1} 55 \%, \mathrm{E}_{0} 30 \%, 19^{\circ} 37^{\prime} 16.5^{\prime \prime} \mathrm{E}, 48^{\circ} 28^{\prime} 54.8^{\prime \prime} \mathrm{N}, 19.8$. 2010, R. Hrivnák \& M. Slezák.

2. Ipel'ský Potok, Dobrý Potok, 432 m, NWW, 2º $400 \mathrm{~m}^{2}, \mathrm{E}_{\mathrm{t}} 80 \%, \mathrm{E}_{3} 80 \%, \mathrm{E}_{2} 1 \%, \mathrm{E}_{1} 70 \%, \mathrm{E}_{0} 5 \%, 19^{\circ} 41^{\prime} 49.3^{\prime \prime} \mathrm{E}, 48^{\circ} 33^{\prime} 31.8^{\prime \prime} \mathrm{N}, 29.7$. 2010, R. Hrivnák \& M. Slezák.

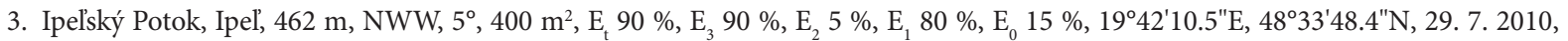
R. Hrivnák \& M. Slezák.

4. Ipel'ský Potok, $415 \mathrm{~m},-, 0^{\circ}, 400 \mathrm{~m}^{2}, \mathrm{E}_{\mathrm{t}} 85 \%, \mathrm{E}_{3} 85 \%, \mathrm{E}_{2} 15 \%, \mathrm{E}_{1} 80 \%, \mathrm{E}_{0} 10 \%, 19^{\circ} 41^{\prime} 11.0^{\prime \prime} \mathrm{E}, 48^{\circ} 33^{\prime} 11.4 " \mathrm{~N}, 29.7 .2010$, R. Hrivnák \& M. Slezák.

5. Ipel’ský Potok, Dobrý Potok, 415 m, -, 0 $0^{\circ}, 400 \mathrm{~m}^{2}, \mathrm{E}_{\mathrm{t}} 90 \%, \mathrm{E}_{3} 90 \%, \mathrm{E}_{2} 5 \%$, E 75 \%, $\mathrm{E}_{0} 15 \%, 9^{\circ} 41^{\prime} 36.2^{\prime \prime} \mathrm{E}, 48^{\circ} 33^{\prime} 25.7^{\prime \prime} \mathrm{N}, 29.7 .2010$, R. Hrivnák \& M. Slezák.

6. Kalinovo, $231 \mathrm{~m},-, 0^{\circ}, 400 \mathrm{~m}^{2}, \mathrm{E}_{\mathrm{t}} 90 \%, \mathrm{E}_{3} 90 \%, \mathrm{E}_{2} 3 \%, \mathrm{E}_{1} 70 \%, \mathrm{E}_{0} 7 \%, 19^{\circ} 43^{\prime} 25.7^{\prime \prime} \mathrm{E}, 48^{\circ} 23^{\prime} 57.3^{\prime \prime} \mathrm{N}, 6.8$. 2010, R. Hrivnák \& M. Slezák.

7. Breznička, $210 \mathrm{~m},-, 0^{\circ}, 400 \mathrm{~m}^{2}, \mathrm{E}_{\mathrm{t}} 90 \%, \mathrm{E}_{3} 90 \%, \mathrm{E}_{2} 0 \%, \mathrm{E}_{1} 75 \%, \mathrm{E}_{0} 4 \%, 19^{\circ} 44^{\prime} 42.6^{\prime \prime} \mathrm{E}, 48^{\circ} 25^{\prime} 24.8^{\prime \prime} \mathrm{N}, 6.8 .2010, \mathrm{R}$. Hrivnák \& M. Slezák.

8. Divín, 260 m, -, $0^{\circ}, 400 \mathrm{~m}^{2}, \mathrm{E}_{\mathrm{t}} 80 \%, \mathrm{E}_{3} 80 \%, \mathrm{E}_{2} 0 \%, \mathrm{E}_{1} 65 \%, \mathrm{E}_{0} 1 \%, 19^{\circ} 32^{\prime} 31.0 " \mathrm{E}, 48^{\circ} 26^{\prime} 37.9^{\prime \prime} \mathrm{N}, 30.6$. 2010, R. Hrivnák \& M. Slezák.

9. Lehota nad Rimavicou, $297 \mathrm{~m},-, 0^{\circ}, 400 \mathrm{~m}^{2}, \mathrm{E}_{\mathrm{t}} 80 \%, \mathrm{E}_{3} 80 \%, \mathrm{E}_{2} 7 \%, \mathrm{E}_{1} 70$ \%, $\mathrm{E}_{0} 5 \%$, 1952'12.9"E, 48³2'01.6"N, 4. 9. 2010, M. Slezák.

10. Lovinobaňa, $242 \mathrm{~m},-, 0^{\circ}, 400 \mathrm{~m}^{2}, \mathrm{E}_{\mathrm{t}} 80 \%, \mathrm{E}_{3} 80 \%, \mathrm{E}_{2} 3 \%, \mathrm{E}_{1} 65 \%, \mathrm{E}_{0} 1 \%, 19^{\circ} 34^{\prime} 41.8^{\prime \prime} \mathrm{E}, 48^{\circ} 25^{\prime} 51.9^{\prime \prime} \mathrm{N}, 30.6 .2010$, R. Hrivnák \& M. Slezák.

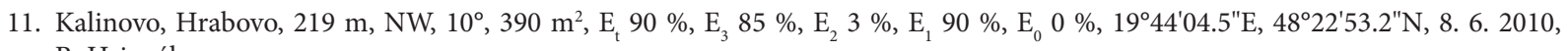
R. Hrivnák.

12. Poltár, Kúpna hora, 255 m, -, $0^{\circ}, 375 \mathrm{~m}^{2}, \mathrm{E}_{\mathrm{t}} 90 \%, \mathrm{E}_{3} 90 \%, \mathrm{E}_{2} 5 \%, \mathrm{E}_{1} 85 \%, \mathrm{E}_{0} 10 \%, 19^{\circ} 48^{\prime} 53.4^{\prime \prime} \mathrm{E}, 48^{\circ} 25^{\prime} 51.8^{\prime \prime} \mathrm{N}, 24.6 .2010$, M. Slezák.

13. Poltár, Kúpna hora, $255 \mathrm{~m},-, 0^{\circ}, 400 \mathrm{~m}^{2}, \mathrm{E}_{\mathrm{t}} 85 \%, \mathrm{E}_{3} 85 \%, \mathrm{E}_{2} 5 \%, \mathrm{E}_{1} 70 \%, \mathrm{E}_{0} 10 \%, 19^{\circ} 49^{\prime} 06.7^{\prime \prime} \mathrm{E}, 48^{\circ} 25^{\prime} 45.0^{\prime \prime} \mathrm{N}, 24.6 .2010$, M. Slezák.

14. Sušany, Krivá dolina valley, 255 m, -, $0^{\circ}, 400 \mathrm{~m}^{2}, \mathrm{E}_{\mathrm{t}} 90 \%, \mathrm{E}_{3} 90 \%, \mathrm{E}_{2} 3 \%, \mathrm{E}_{1} 80 \%, \mathrm{E}_{0} 2 \%, 9^{\circ} 54^{\prime} 04.4^{\prime \prime} \mathrm{E}, 48^{\circ} 25^{\prime} 41.6^{\prime \prime} \mathrm{N}, 5.6 .2010$, M. Slezák.

15. Tomášovce, $225 \mathrm{~m},-, 0^{\circ}, 400 \mathrm{~m}^{2}, \mathrm{E}_{\mathrm{t}} 85 \%, \mathrm{E}_{3} 80 \%, \mathrm{E}_{2} 40 \%, \mathrm{E}_{1} 15 \%, \mathrm{E}_{0} 10 \%, 19^{\circ} 38^{\prime} 47.0^{\prime \prime} \mathrm{E}, 48^{\circ} 23^{\prime} 05.0^{\prime \prime} \mathrm{N}, 30.6 .2010$, R. Hrivnák \& M. Slezák.

16. Maštinec, $233 \mathrm{~m},-, 0^{\circ}, 400 \mathrm{~m}^{2}, \mathrm{E}_{\mathrm{t}} 80 \%, \mathrm{E}_{3} 80 \%, \mathrm{E}_{2} 30 \%, \mathrm{E}_{1} 70 \%, \mathrm{E}_{0} 20 \%, 19^{\circ} 49^{\prime} 11.5^{\prime \prime} \mathrm{E}, 48^{\circ} 23^{\prime} 40.9^{\prime \prime} \mathrm{N}, 9.7$. 2010, M. Slezák.

17. Slaná Lehota, $240 \mathrm{~m},-, 0^{\circ}, 400 \mathrm{~m}^{2}, \mathrm{E}_{\mathrm{t}} 80 \%, \mathrm{E}_{3} 80 \%, \mathrm{E}_{2} 15 \%, \mathrm{E}_{1} 65 \%, \mathrm{E}_{0} 10 \%, 19^{\circ} 47^{\prime} 18.5^{\prime \prime} \mathrm{E}, 48^{\circ} 27^{\prime} 15.1^{\prime \prime N}$, 19. 7. 2010, M. Slezák. 
18. Sušany, Jelené, $258 \mathrm{~m},-, 0^{\circ}, 400 \mathrm{~m}^{2}, \mathrm{E}_{\mathrm{t}} 90 \%, \mathrm{E}_{3} 90 \%, \mathrm{E}_{2} 10 \%, \mathrm{E}_{1} 70 \%, \mathrm{E}_{0} 3 \%, 1^{\circ} 54^{\prime} 24.7^{\prime \prime} \mathrm{E}, 48^{\circ} 25^{\prime} 43.9^{\prime \prime} \mathrm{N}, 2.8$. 2010, M. Slezák.

19. Poltár, Kúpna hora, $265 \mathrm{~m},-, 0^{\circ}, 400 \mathrm{~m}^{2}, \mathrm{E}_{\mathrm{t}} 95 \%, \mathrm{E}_{3} 90 \%, \mathrm{E}_{2} 3 \%, \mathrm{E}_{1} 95 \%, \mathrm{E}_{0} 5 \%, 9^{\circ} 49^{\prime} 23.5^{\prime \prime} \mathrm{E}, 48^{\circ} 25^{\prime} 57.2^{\prime \prime N}$, 24. 6. 2010, M. Slezák.

20. Mýtna, $290 \mathrm{~m},-, 0^{\circ}, 400 \mathrm{~m}^{2}, \mathrm{E}_{\mathrm{t}} 80 \%, \mathrm{E}_{3} 80 \%, \mathrm{E}_{2} 3 \%, \mathrm{E}_{1} 70 \%, \mathrm{E}_{0} 2 \%, 19^{\circ} 31^{\prime} 09.8^{\prime \prime} \mathrm{E}, 48^{\circ} 28^{\prime} 51.9^{\prime \prime N}$, 14. 7. 2010, M. Slezák.

21. Kalinovo, Briežky, $254 \mathrm{~m},-, 0^{\circ}, 400 \mathrm{~m}^{2}, \mathrm{E}_{\mathrm{t}} 85 \%, \mathrm{E}_{3} 85 \%, \mathrm{E}_{2} 15 \%, \mathrm{E}_{1} 75 \%, \mathrm{E}_{0} 10 \%, 19^{\circ} 41^{\prime} 05.8^{\prime \prime} \mathrm{E}, 48^{\circ} 24^{\prime} 53.2^{\prime \prime} \mathrm{N}, 8.6 .2010$, R. Hrivnák.

22. Uhorské, $285 \mathrm{~m},-, 0^{\circ}, 400 \mathrm{~m}^{2}, \mathrm{E}_{\mathrm{t}} 90 \%, \mathrm{E}_{3} 90 \%, \mathrm{E}_{2} 2 \%, \mathrm{E}_{1} 70 \%, \mathrm{E}_{0} 5 \%, 19^{\circ} 46^{\prime} 07.1^{\prime \prime} \mathrm{E}, 48^{\circ} 28^{\prime} 28.8^{\prime \prime} \mathrm{N}, 19.7 .2010$, M. Slezák.

23. Lučenec, Koháryho dolina valley, $265 \mathrm{~m},-, 0^{\circ}, 400 \mathrm{~m}^{2}, \mathrm{E}_{\mathrm{t}} 80 \%, \mathrm{E}_{3} 80 \%, \mathrm{E}_{2} 15 \%, \mathrm{E}_{1} 70 \%, \mathrm{E}_{0} 10 \%, 19^{\circ} 37^{\prime} 58.5^{\prime \prime} \mathrm{E}, 48^{\circ} 18^{\prime} 03.4^{\prime \prime} \mathrm{N}, 6.8$. 2010, M. Slezák.

24. Selce, $276 \mathrm{~m},-, 0^{\circ}, 400 \mathrm{~m}^{2}, \mathrm{E}_{\mathrm{t}} 90 \%, \mathrm{E}_{3} 90 \%, \mathrm{E}_{2} 2 \%, \mathrm{E}_{1} 85 \%, \mathrm{E}_{0} 13 \%, 19^{\circ} 52^{\prime} 07.3^{\prime \prime} \mathrm{E}, 48^{\circ} 18^{\prime} 22.7^{\prime \prime} \mathrm{N}, 14.8$. 2010, M. Slezák.

25. Mučín, $229 \mathrm{~m},-, 0^{\circ}, 400 \mathrm{~m}^{2}, \mathrm{E}_{\mathrm{t}} 90 \%, \mathrm{E}_{3} 90 \%, \mathrm{E}_{2} 5 \%, \mathrm{E}_{1} 70 \%, \mathrm{E}_{0} 10 \%, 19^{\circ} 40^{\prime} 28.8^{\prime \prime} \mathrm{E}, 48^{\circ} 14^{\prime} 54.0^{\prime \prime N}, 24.7 .2010$, M. Slezák.

26. Malé Dálovce, Frenčok, $210 \mathrm{~m},-, 0^{\circ}, 400 \mathrm{~m}^{2}, \mathrm{E}_{\mathrm{t}} 75 \%, \mathrm{E}_{3} 70 \%, \mathrm{E}_{2} 15 \%, \mathrm{E}_{1} 75 \%, \mathrm{E}_{0} 7 \%, 19^{\circ} 33^{\prime} 40.4^{\prime \prime} \mathrm{E}, 48^{\circ} 16^{\prime} 08.6^{\prime \prime} \mathrm{N}, 7.9 .2010$, R. Hrivnák \& M. Slezák.

27. Lovinobaňa, 329 m, -, $0^{\circ}, 400 \mathrm{~m}^{2}, \mathrm{E}_{\mathrm{t}} 75 \%, \mathrm{E}_{3} 75 \%, \mathrm{E}_{2} 10 \%, \mathrm{E}_{1} 65 \%, \mathrm{E}_{0} 1 \%, 19^{\circ} 37^{\prime} 12.8^{\prime \prime} \mathrm{E}, 48^{\circ} 26^{\prime} 53.8^{\prime \prime} \mathrm{N}, 19.8$. 2010, R. Hrivnák \& M. Slezák.

28. Kotmanová, 280 m, NWW, 2 $2^{\circ}, 400$ m² $^{2} \mathrm{E}_{\mathrm{t}} 90 \%, \mathrm{E}_{3} 90 \%, \mathrm{E}_{2} 3 \%, \mathrm{E}_{1} 70 \%, \mathrm{E}_{0} 3 \%, 1^{\circ} 35^{\prime} 27.1^{\prime \prime E}, 48^{\circ} 29^{\prime} 48.1^{\prime \prime N}, 19.8 .2010$, R. Hrivnák \& M. Slezák.

29. Lovinobaňa, $248 \mathrm{~m}, \mathrm{NE}, 2^{\circ}, 400 \mathrm{~m}^{2}, \mathrm{E}_{\mathrm{t}} 85 \%, \mathrm{E}_{3} 85 \%, \mathrm{E}_{2} 30 \%, \mathrm{E}_{1} 80 \%, \mathrm{E}_{0} 2 \%, 9^{\circ} 34^{\prime} 33.9^{\prime \prime} \mathrm{E}, 48^{\circ} 25^{\prime} 47.8^{\prime \prime} \mathrm{N}, 30.6$. 2010, R. Hrivnák \& M. Slezák.

Table 2: Means and standard deviations are given for each environmental variable including Ellenberg indicator values (EIV), Shannon-Wiener index ( $\mathrm{SW}$ - index) and measured parameters ( $\mathrm{pH}$ - soil reaction, $\mathrm{C} / \mathrm{N}-\mathrm{C} / \mathrm{N}$ ratio, $\mathrm{N}_{\text {Tот }}$ - total content of N, $\mathrm{C}_{\text {Tот }}$ - total content of C). Significant differences among the clusters in one-way ANOVA and post-hoc Newman-Keuls test at $P<0.05$ are marked by different letters (a, b, c).

Tabela 2: Povprečja in standardni odkloni za okoljske spremenljivke in Ellenbergove indikatorske vrednosti (EIV), Shannon-Wienerjev indeks ( $\mathrm{SW}$ - index) in merjeni parametri ( $\mathrm{pH}$ - reakcija tal, $\mathrm{C} / \mathrm{N}-\mathrm{C} / \mathrm{N}$ razmerje, $\mathrm{N}_{\text {тот }}$ skupna vsebnost $\mathrm{N}, \mathrm{C}_{\text {тот }}$ - skupna vsebnost $\mathrm{C}$ ). Statistično značilne razlike med klastri (enosmerna ANOVA in post-hoc Newman-Keuls-ov test pri $\mathrm{P}<0.05)$ so označene $\mathrm{z}$ različnimi črkami $(\mathrm{a}, \mathrm{b}, \mathrm{c})$.

Cluster

\begin{tabular}{lcccc} 
& $\mathrm{A}$ & $\mathrm{B}$ & $\mathrm{C} 1$ & $\mathrm{C} 2$ \\
Number of relevés & 5 & 5 & 10 & 9 \\
\hline EIV - Light & $5.61 \pm 0.22^{\mathrm{a}}$ & $6.02 \pm 0.20^{\mathrm{b}}$ & $5.64 \pm 0.36^{\mathrm{a}}$ & $5.28 \pm 0.25^{\mathrm{a}}$ \\
EIV - Temperature & $5.15 \pm 0.07^{\mathrm{b}}$ & $5.35 \pm 0.08^{\mathrm{a}}$ & $5.37 \pm 0.12^{\mathrm{a}}$ & $5.30 \pm 0.06^{\mathrm{a}}$ \\
EIV - Continentality & $3.66 \pm 0.16^{\mathrm{a}}$ & $3.69 \pm 0.14^{\mathrm{a}}$ & $3.67 \pm 0.14^{\mathrm{a}}$ & $3.59 \pm 0.12^{\mathrm{a}}$ \\
EIV - Moisture $*$ & $7.25 \pm 0.25^{\mathrm{bc}}$ & $7.49 \pm 0.32^{\mathrm{c}}$ & $6.69 \pm 0.33^{\mathrm{ab}}$ & $6.46 \pm 0.29^{\mathrm{a}}$ \\
EIV - Soil Reaction & $6.27 \pm 0.16^{\mathrm{a}}$ & $6.43 \pm 0.16^{\mathrm{a}}$ & $6.46 \pm 0.18^{\mathrm{a}}$ & $6.51 \pm 0.14^{\mathrm{a}}$ \\
EIV - Nutrients & $5.92 \pm 0.21^{\mathrm{a}}$ & $6.08 \pm 0.28^{\mathrm{ab}}$ & $6.24 \pm 0.26^{\mathrm{ab}}$ & $6.39 \pm 0.39^{\mathrm{b}}$ \\
SW - index & $2.87 \pm 0.26^{\mathrm{a}}$ & $2.54 \pm 0.32^{\mathrm{a}}$ & $2.57 \pm 0.24^{\mathrm{a}}$ & $2.78 \pm 0.17^{\mathrm{a}}$ \\
Altitude (m) & $419 \pm 33^{\mathrm{b}}$ & $248 \pm 33^{\mathrm{a}}$ & $250 \pm 21^{\mathrm{a}}$ & $264 \pm 35^{\mathrm{a}}$ \\
Conductivity $(\mu \mathrm{S} / \mathrm{cm})$ & $300.32 \pm 166.17^{\mathrm{ab}}$ & $416.10 \pm 203.25^{\mathrm{b}}$ & $259.52 \pm 124.94^{\mathrm{ab}}$ & $203.19 \pm 68.34^{\mathrm{a}}$ \\
pH & $5.15 \pm 0.44^{\mathrm{a}}$ & $5.71 \pm 0.68^{\mathrm{a}}$ & $5.61 \pm 0.52^{\mathrm{a}}$ & $5.61 \pm 0.69^{\mathrm{a}}$ \\
C/N & $12.14 \pm 0.52^{\mathrm{a}}$ & $13.04 \pm 1.92^{\mathrm{a}}$ & $12.44 \pm 1.03^{\mathrm{a}}$ & $12.75 \pm 1.73^{\mathrm{a}}$ \\
$\mathrm{N}_{\text {Tот }}(\%)$ & $0.86 \pm 0.62^{\mathrm{ab}}$ & $1.15 \pm 0.72^{\mathrm{b}}$ & $0.48 \pm 0.36^{\mathrm{a}}$ & $0.39 \pm 0.21^{\mathrm{a}}$ \\
$\mathrm{C}_{\text {Tот }}(\%)$ & $10.56 \pm 7.98^{\mathrm{ab}}$ & $14.71 \pm 9.06^{\mathrm{b}}$ & $6.00 \pm 4.91^{\mathrm{a}}$ & $4.83 \pm 2.44^{\mathrm{a}}$ \\
Sand (\%) & $40.06 \pm 14.30^{\mathrm{a}}$ & $24.96 \pm 11.01^{\mathrm{a}}$ & $24.74 \pm 17.45^{\mathrm{a}}$ & $33.76 \pm 19.76^{\mathrm{a}}$ \\
Silt (\%) & $56.15 \pm 12.45^{\mathrm{a}}$ & $69.62 \pm 10.15^{\mathrm{a}}$ & $63.33 \pm 18.85^{\mathrm{a}}$ & $60.30 \pm 16.78^{\mathrm{a}}$ \\
Clay $(\%)$ & $3.28 \pm 1.51^{\mathrm{a}}$ & $5.19 \pm 1.24^{\mathrm{a}}$ & $11.82 \pm 16.43^{\mathrm{a}}$ & $5.85 \pm 3.24^{\mathrm{a}}$ \\
\hline
\end{tabular}

Note: ${ }^{\star}$ Kruskal-Wallis ANOVA (see also Methods) 